Florida International University

FIU Digital Commons

FIU Electronic Theses and Dissertations

University Graduate School

3-30-2011

\title{
The Hindu-Jewish relationship and the significance of dialogue : participants' reflections on the 2007 and 2008 Hindu-Jewish summits at New Delhi and Jerusalem
}

Michael Mclean Bender

Florida International University

DOI: $10.25148 /$ etd.FI14050497

Follow this and additional works at: https://digitalcommons.fiu.edu/etd

Part of the Religious Thought, Theology and Philosophy of Religion Commons

\section{Recommended Citation}

Bender, Michael Mclean, "The Hindu-Jewish relationship and the significance of dialogue : participants' reflections on the 2007 and 2008 Hindu-Jewish summits at New Delhi and Jerusalem" (2011). FIU Electronic Theses and Dissertations. 1500.

https://digitalcommons.fiu.edu/etd/1500 
FLORIDA INTERNATIONAL UNIVERSITY

Miami, Florida

THE HINDU-JEWISH RELATIONSHIP AND THE SIGNIFICANCE OF DIALOGUE:

PARTICIPANTS`REFLECTIONS ON THE 2007 AND 2008 HINDU-JEWISH

SUMMITS AT NEW DELHI AND JERUSALEM

A thesis submitted in partial fulfillment of the

requirements for the degree of

MASTER OF ARTS

in

RELIGIOUS STUDIES

by

Michael Mclean Bender

2011 
To: Dean Kenneth Furton

College of Arts and Sciences

This thesis, written by Michael Mclean Bender, and entitled The Hindu-Jewish

Relationship and the Significance of Dialogue: Participants' reflections on the 2007 and 2008 Hindu-Jewish Summits at New Delhi and Jerusalem, having been approved in respect to style and intellectual content, is referred to you for judgment.

We have read this thesis and recommend that it be approved.

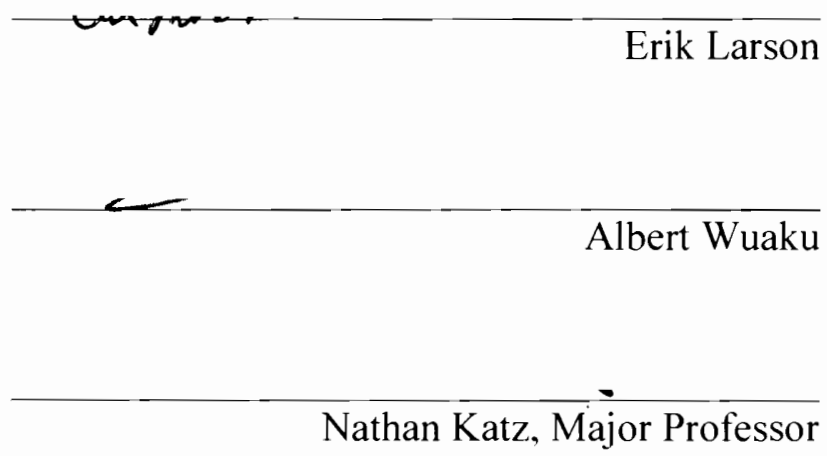

Date of Defense: March 30, 2011

The thesis of Michael Mclean Bender is approved.

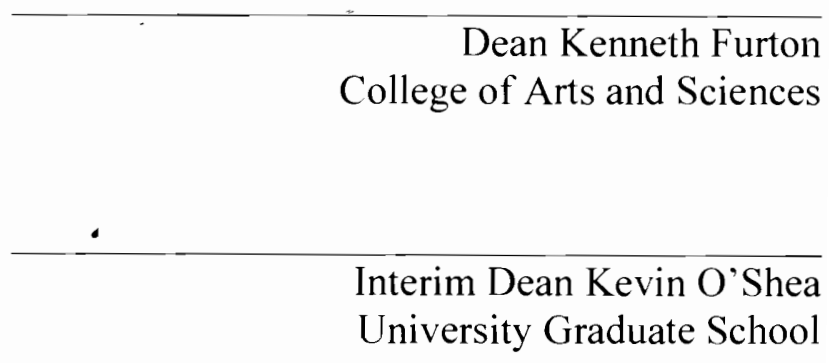

Florida International University, 2011 


\section{ACKNOWLEDGMENTS}

I would like to thank my committee members for their support and guidance throughout my research and writing and the religious studies department at Florida International for providing me with a teaching assistantship, which gave me the opportunity to complete this research and obtain my degree. I would also like to thank the Greater Miami Jewish Federation, the Florida International University Program in the Study of Spirituality, and the Graduate Student Association for their generosity in funding my research. Finally, I would like to give a special thanks to Dr. Nathan Katz, whose mentorship has been invaluable to my academic experience, and Mr. Bawa Jain of the World Council of Religious Leaders without whom, none of my research would have been possible. 


\begin{abstract}
OF THE THESIS
THE HINDU-JEWISH RELATIONSHIP AND THE SIGNIFICANCE OF DIALOGUE: PARTICIPANTS' REFLECTIONS ON THE 2007 AND 2008 HINDU-JEWISH SUMMITS AT NEW DELHI AND JERUSALEM
\end{abstract}

by

Michael Mclean Bender

Florida International University, 2011

Miami, Florida

Professor Nathan Katz, Major Professor

The purpose of this study was to determine whether or not new and significant developments for the Hindu and Jewish faiths, and the relationship that exists between them, can be demonstrated from the results of the Hindu-Jewish Leadership Summits of 2007 and 2008 in Delhi and Jerusalem. I argue that new and significant developments can be observed with this Hindu-Jewish encounter with regards to official rulings of Halacha (Jewish law), proper understandings of sacred symbols of Hinduism, and even improved Islamic-Jewish relations.

After analyzing the approaches, themes, and unique framework found within this encounter, it is clear that the Hindu-Jewish leadership summits mark new and significant developments in inter-religious dialogue between the two traditions, culminating in the redefinition of Hinduism as a monotheistic religion. 


\section{TABLE OF CONTENTS}

CHAPTER

PAGE

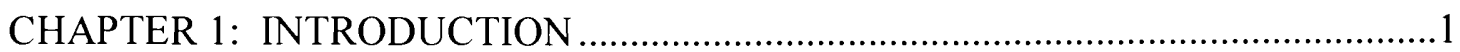

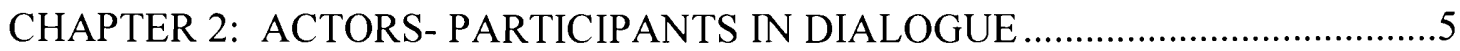

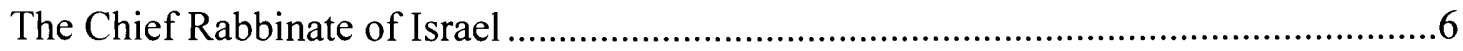

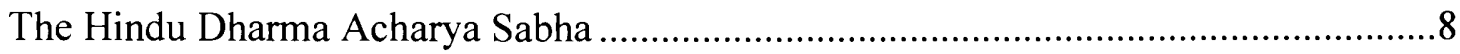

CHAPTER 3: HISTORY, THEORIES, \& APPROACHES

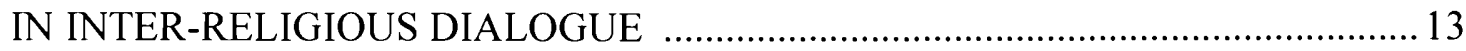

CHAPTER 4: METHODS- ADVENTURES IN THE FIELD! .....................................2

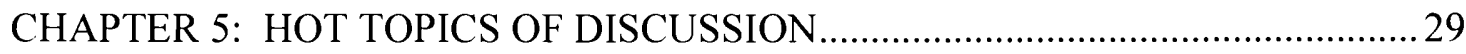

A New Type of Dialogue: A Non-Universal Meeting With Universal Implications .... 31

Cultural Threats: The Challenge of Secularization \& Terrorism.................................... 38

Proselytization: The Destructive Nature of Conversion .................................................. 49

Self-Defining Identity: History, Symbols, \& Monotheism............................................56

CHAPTER 6: CONCLUDING THOUGHTS \& ARGUMENTS ................................67

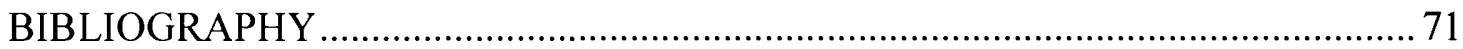

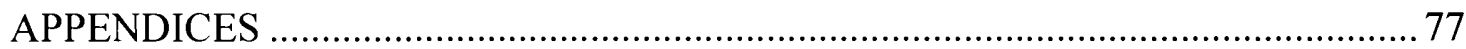




\section{Chapter 1: Introduction}

When I visited R. Joshua Kolet, one of the few persons with smikhe (rabbinic ordination) in Thane, near Bombay, little did I expect the bombshell that he laid on me!

On his invitation, I visited him erev shabes, parshes beshallakh (in the Jewish tradition, the Pentateuch is divided into different parshes or divisions, which are read on Saturday: the weeks are, then, often referred to by the name of the parshe read on the Sabbath of that week). Friday night, we were talking about the parshe and structure of the nisyoynes (troubles) that befell Bnei Yisroel (the Jewish nation). Joshua had his own interpretations of the parshe that partly complemented and partly countered mine (which I had, incidentally, taken from R. Liebtag). As we chatted, Joshua and I started talking about Hinduism and avoyde zore (loosely translated in English as idolatry). Joshua, who had spent a couple of years in Israel learning about pedagogy and then decided to spend a few more years getting smikhe from a Sephardic Yeshiva, had not lost his independent spirit. He suggested to me, based on the text in devorim (Deuteronomy) that hashem (God) in the khumesh (Pentateuch) was quite willing to speak in terms of gods, and it was only with the midrash and gemore that a more uncompromising attitude toward elilim akheyrim (foreign gods) developed.

I talked to him about my own ideas as to the essential similarity of Judaism and Hinduism. At this point, he dropped his bombshell! "I don't know if you're aware of this," he said, "but the Ashkenazic Chief Rabbi is visiting India this coming week to dialogue with the Shankaracharya (the most respected Hindu leader in India)." He suggested that I might be an appropriate addition to the Jewish delegation given my knowledge of both Hinduism and Judaism. He promised to talk to the organizers in Delhi to see if they would invite me as well. (Viswanath, 2007)

This anecdote is that of Dr. P.V. Viswannath, Pace University professor of finance at the Lubin School of Business and an Orthodox Jew of Indian decent. The intriguing question dealing with the Hindu concept of the divine that is spoken of here is just one of the few issues that are at the very heart of the Hindu-Jewish encounter. His described reaction in learning about this meeting was by no means an overstatement and, on the contrary, this news was met with an elated surprise that reverberated throughout the world of inter-religious dialogue, its academics, and its participants. 
In the contemporary world a variety of relationships can be observed to exist between different religious groups. They historically range from the economic to the political to the practical. Some meet in the context of conducting business, while others in an effort to solve a mutual or communal problem. Interaction between individuals of different religious backgrounds takes place at every level from the everyday, lay practitioner to the highest ranks of religious leadership. Some of the most recognizable interaction between religious groups is seen in formal meetings between religious leaders. A formal interaction between two groups, in this case religious groups, is termed as a 'dialogue' and Charles Kimball states it best when he defines this term as:

A conversation, a process of communication through speech. It is a reciprocal relationship in which two or more parties endeavor both to express accurately what they mean and to listen to and respect what the other person says, however different his or her perspective may be. Fundamentally, it is a perspective, a stance, an openness. Dialogue represents a way of relating. Ideally, mutuality in dialogue is present in communication, trust, understanding, challenge, growth, and even spiritual development. (Pratt, 2005, p. 195).

This definition of dialogue, in relation to religion, is known as "inter-faith" or "interreligious." Dialogue provides an invaluable platform for traditions to speak to and understand one another during a day and age where such formal encounters between religious leaders are becoming key to peaceful relations within and among nations and peoples.

In the last four years a relationship has been budding between Hindu and Jewish leaders as a result of dialogue. My study focuses on the 2008 and 2009 Hindu-Jewish summits which took place in New Delhi and Jerusalem, respectively. This initiative was began because of Mr. Bawa Jain, Secretary General of the World Council of Religious Leaders, a New York-based NGO. The idea to put together such a meeting between 
Hindu and Jewish groups was conceived by Mr. Jain in 2003 following the 3L (Look, Listen, and Learn) initiative of the World Council of Religious Leaders (Jain, 2007). It was here that he spoke with Mr. Oded Wiener, Director General of the Chief Rabbinate of Israel, about the Rabbinate's engagement in various dialogues and learned of the rapid progress they had made with the Abrahamic religions through the process of dialogue (Jain, 2007). Following this meeting, Mr. Jain met with Swami Dayananda Saraswati to propose a meeting between the Hindu Dharma Acharya Sabha and the Chief Rabbinate of Israel. Swami Dayanada promptly embraced the idea and, in three years time, the first summit was launched in Delhi, India (Jain, 2007).

This dialogue was clearly something new for each tradition in a sense that it was the first time that such prominent leaders from the two traditions met, but what is its significance to the to the Hindu and Jewish worlds? Is there something new to be found at these meetings with reference to inter-faith relations between the two traditions? As the participants claim, and as my fieldwork seems to demonstrate, there is something novel and significantly important to be found here in the Hindu-Jewish encounter with regards Hindu-Jewish relations and their inter-religious dialogue. Also, it is a relationship with the potential to have a profound impact on the greater world of international relations in the very near future because of the partnerships that could be formed. This relationship could shift the balance of power in Asia by creating a three way alliance which would also include Israel's and India's common ally, the United States.

Therefore, the question I seek to explore in this study is whether or not these two historic encounters that took place in Delhi and in Jerusalem demonstrate new and 
significant developments for the Hindu and Jewish traditions and the dialogue process between the two. I argue in this work that new and significant developments can be observed with this Hindu-Jewish encounter with regards to official rulings of Halacha (Jewish law), proper understandings of sacred symbols of Hinduism, and even improved Islamic-Jewish relations. In fact, the summit marked a distinct shift within relations between Hinduism and Judaism, for the Chief Rabbinate reversed the definitive charge of idolatry against Hindus. My conclusions were arrived at through the critical analysis of 'summit reports' that detail the themes and topics that informed and guided the meetings at Delhi and Jerusalem. In addition, I performed ethnographic work in India and Israel which primarily consisted of interviewing participants of these meetings. These interviews were critical in supporting and expanding on information gathered from the summit reports.

This work is divided into five chapters and is structured as follows. In Chapter 1, I have given an introduction to the study and my thesis statement. Chapter 2 details a brief history of the two main delegations involved in these meetings, the Chief Rabbinate of Israel and the Hindu Dharma Acharya Sabha. Chapter 3 discusses theory and approach towards inter-religious dialogue as well as the methods I used in both preparing for my research and in the field. The fourth chapter describes major themes from this encounter which demonstrate the novelty in an inter-faith dialogue between the two groups and the significant development the encounter has produced for the Hindu and Jewish traditions. In the fifth, and final, chapter I state my concluding arguments. 


\section{Chapter 2: Actors- Participants in Dialogue}

This following section will describe the representatives of the two main parties

involved the summits. Representing the Jewish delegation was the Chief Rabbinate of Israel and representing the Hindu side was the umbrella group, the Hindu Dharma Acharya Sabha. The Chief Rabbinate of Israel represents the interests of orthodox Jewry in Israel and, to a certain extent, around the world. The Chief Rabbinate gains authority from the power and influence it holds within Israeli society as well as from its recognition as an institution of religious authority dating back 90 years in the case of the Ashkenazic Chief Rabbinate and approximately 150 years in the case of the Sephardic Chief Rabbinate. The HDAS is a Hindu umbrella group consisting of swamis from several different traditions that represents one of the first attempts at providing a representative body for Hindu religious interests. It strives to be the representative body for all Hindus, with regards to religious matters, in a tradition that historically has had no hierarchy or central leadership to guide and unite practitioners.

Hindu-Jewish relations have existed for centuries and the history of this relationship provides fitting examples as to why the groups continue to have genuinely friendly relations. The Hindus and the Jews are not strangers to one another, although their acquaintance was unknown until the modern age, quite the contrary in fact. Contact between the two groups may date back as far as one thousand BCE as the Hebrew Bible may indicate by it's possible description of trade between Solomon's kingdom and India, 
in addition to containing no less than four Hebrew words of Indic origin, including the terms for cinnamon, emerald, sapphire, and topaz (Katz, 1999, p. 13).

There is also the unique experience the Jews of India have had, characterized by overwhelmingly just treatment by Indian rulers, which dates back nearly two millennia and has assisted in easing the way for friendly relations today. Rabbi Abraham Benjamin, rabbi of India, stated at the first summit in Delhi, "We [the Jews] were never in fear of observing any of our customs, or losing our traditional ways. We never faced persecution. This is what India has given to the Jewish community" (Benjamin, 2007).

\section{The Chief Rabbinate of Israel}

In Israel today there exists a Chief Rabbinate for both Ashkenazic as well as Sephardic Jewish ethnic groups. The headquarters of the Chief Rabbinate is located in Beit Yahav in Jerusalem (Fendel, 2008) and, together, they command control over all religious affairs in Israel. They both serve on equal footing as joint chairmen on the Chief Rabbinate Council (Schwarzfuchs, 1993, p.138). Although both of these Chief Rabbis were involved in the summits, it was the only Ashkenazic rabbinate who took part in the Delhi and Jerusalem meetings. It should also be noted that the Ashkenazic Chief Rabbi played a much more central role in the meeting process as a whole.

The official term of 'Chief Rabbinate' was first applied to the supreme religious authority of the Jewish community by the British in what was then Palestine in the year 1921. It was also at this time that the institution of the Chief Rabbi was split into two separate, but equal powers, giving birth to the position of Ashkenazic Chief Rabbi while recognizing the continuing authority of the Sephardic rabbi as well. This came as a 
response, in part, to the increasing numbers of Ashkenazic Jews immigrating to Palestine who wanted recognition and it was therefore at this time that the British overlords of Palestine decided to implement this as an official position in Israel (Schwarzfuchs, 1993, p138). In 1928 the Knesset Israel, which included the institution of the Chief Rabbinate, was recognized by British authorities as the official representative body of Jewish individuals in Palestine (Schwarzfuchs, 1993, p.138).

Currently, chief rabbis are chosen via a voting process by an electoral body consisting of rabbis as well as lay persons recruited by mayors of Israeli cities and terms of service last for a period of ten years with no possibility for re-election (Schwarzfuchs, 1993, p.139). It is also worthy to note that a de facto hierarchy has been established within the institution of the Chief Rabbinate as a result of the different regulations and laws that govern it (Schwarzfuchs, 1993, p.140). The Chief Rabbinate Council is comprised of 16 rabbis: Six permanent members - the two Chief Rabbis of Israel, and the Chief Rabbis of Jerusalem, Tel Aviv, Haifa and Be'er Sheva - and ten other rabbis (Fendel, 2008).

The history and origin of the Sephardic Chief Rabbinate goes back to the middle of the nineteenth century and pre-dates that of the Ashkenazic. Beginning in 1836, there is evidence of the term Hakham Bashi, which means chief or head rabbi, being used with reference to a chosen, central Jewish authority in the Ottoman Empire (Schwarzfuchs 1993, p.72). This position was fully recognized within the Ottoman Empire in the year 1864 when an official decree went out which stated:

The chief rabbi is the head of the whole Jewish nation which resides in the Ottoman Empire; he shall carry out the orders of the imperial government. He must therefore enjoy the trust and the confidence of the government and the nation, and be endowed with good qualities, be a good 
Ottoman subject, and descend from Ottoman parents and grandparents (Schwarzfuchs, p.72, 1993).

First mentioned in the 1840 's, this rabbi resided in Jerusalem and was referred to by the unique name of Rishon-le Zion which means, 'the first at Zion' (Schwarzfuchs, 1993, p.137). The Sephardic chief rabbi was the first of the two rabbis to exist in present-day Israel which explains why he is the only one referred to as Rishon-le Zion.

The Ashkenazic Chief Rabbi, as well as the Sephardic Chief Rabbi, take up many of the same responsibilities and perform the same functions for their respective communities. They are the spiritual and halachic authorities of the Jewish community in Israel. They are responsible for rulings in religious law and supervise the system of Kashrut that is in place in the Israeli state. They are in control of the religious courts that preside over Israel and have control over areas of marriage, divorce, and burial rites within the Jewish world, areas over which they have sole control over.

\section{The Hindu Dharma Acharya Sabha}

The Hindu Dharma Acharya Sabha's mission is to be "a unifying body that provides leadership, guidance and a collective voice for the Hindus ('The Hindu dharma')." According to them, this organization provides a typically unorganized, divided religious community with the platform and the means to come together, to be acknowledged, and to be heard throughout the world.

The formulation of the HDAS was due in large part to the undertakings of Swami Dayananda Saraswati who is recognized as the founder of the HDAS. It is crucial to 
understand that, without his effort and determination, this organization would not exist and this collective voice of Hindus may not be heard in any type of organized fashion today. Another sense of his importance can be understood by the comments of Sri Venkatanarayanan, general secretary of the Acharya Sabha, when he stated that, "the Acharya Sabha owes its birth to the vision and tireless personal labour of Swami Dayananda Saraswati, a great scholar in Hindu religious philosophy, a Vedanta teacher and a great writer" (personal communication, November 19, 2009). Therefore, it is with him that this idea of a unified, religiously Hindu voice is put into motion for the first time in Indian history.

The hard work and dedication of Swami Dayananda Saraswati culminated in the year 2000 when the Hindu Dharma Acharya Sabha was created and came into being; although only on paper at this point (Puri, 2006b). It could not be described as complete until late 2003 when the apex body of the Hindu Dharma Acharya Sabha that he formed convened for their first ever conference in Chennai, Tamil Nadu. Beginning on November $29^{\text {th }}$ and ending on December $1^{\text {st }}$, members of the newly formed HDAS defined certain core issues to address that are facing modern Hindu society, as well as India in general (Puri, 2006a).

Since the initial success of the first gathering held in Chennai, the HDAS has organized and participated in several other successful conferences throughout the past six years that have taken place in India as well as other parts of the world including Israel and the United States. The issues and concerns deliberated upon at these conferences are at the heart of the mission of the HDAS and the impact they aim to have in the world. 
One of the first steps in this process of unification involved the bringing together of Hinduism's many Sankaracharyas and the leaders of its various ancient Sampradayas or 'schools of thought'. According to Sri Venkatanarayanan, initiation into the HDAS requires the ancient Matha or Peetha Head to write to the HDAS who, in turn, will make some inquiries, which eventually leads to a decision on the acceptance of that particular Sampradaya (personal communication, November 16, 2009). I would like to clarify the term 'ancient' here with Sri Venkatanarayanan's statement that "ancient means at least some centuries old with a continuing lineage to the present" (personal communication, November 16, 2009). The ancient lineage is one of the most important criteria for acceptance into the HDAS. A Sampradaya must have a long history of recognition as a legitimate 'school of thought' among the general Hindu consensus as well as accepted Hindu leaders while being part of a proper line of succession for at least two centuries.

Today, there are approximately 145 members of the HDAS from all the major Sampradayas, a number that does not exceed two dozen, and nearly all major Hindu religious leaders being represented amongst this number (Venkatanarayanan, personal communication, November 15,2009 ). This group therefore claims to represent all Sampradayas of significance within India. The various Heads of these Sampradayas make up the membership of the HDAS.

The following is a list of some of the Sampradayas that are presently members of the HDAS and are active in its mission and undertakings: Advaita, Dvaita, Vaishnava, Sena Sampradaya, Lingayat, Saivadheenam, Varkari, Vallabhacharya, Nimbarka, Swaminarayan, Sudhhadvaita Pushtimarga Vaishnava, and Kabir Panth ("The Hindu dharma"). Each Sampradaya may have more than one Matha or Peetha as a member of 
HDAS and, in fact, some have several because the HDAS is not constituted on the basis of one seat for one Sampradaya (Venkatanarayanan, personal communication, November $16,2009)$.

The organization of the HDAS is at both national and regional levels. At the national level, it is a forum known as the "Sabha." The Sabha is made up of the heads of the various Sampradayas that meet the criteria I described earlier. The members of this Sabha are the ones who form the apex body of the Hindu Dharma (Puri, 2006b) and are the major leaders present at national, and international conferences. This apex body is convened by Swami Dayananda Saraswati at all conferences and meetings. Spokesmen for the HDAS point out that this is not a position of power, however, as they claim there is no "hierarchy" in this organization and all members of the Sabha are on equal footing with one another (Venkatanarayanan, personal communication, November 15, 2009).

The regional bodies are set up for the convenience of members in different regions to allow them to meet more frequently for specific concerns or issues particular to themselves or their region (Venkatanarayanan, personal communication, November 25, 2009). These are smaller groups of Acharyas, each with its own convener ("Hindu dharma").

At the most basic level of the mission of the HDAS is the preservation of the collective Hindu "voice". This was emphasized at their second conference, held in 2005. One of the declarations read as:

The various Sampradaya constitute Hindu Dharma. In fact Hindu Dharma is the collective of the Sampradaya. In as much as the Acharya Sabha has such a large membership comprising virtually all Sampradaya, the Sabha is committed to speak for Hindu Dharma and represent the interests and views 
of the Hindu population in the country and overseas. For the same reason the Acharya Sabha shall engage in discussion with anyone or any country or any government or any other entity including those representing different religions, on matters of importance to Hindus. ("Mumbai convention resolution", 2007)

Universal religious tolerance, as well as religious tolerance within the vastness of Hinduism, is a practice that is upheld and perpetuated in the declarations of the HDAS. The HDAS works to combat efforts to challenge and crack down on proselytization within India and openly voices its opposition to the practice of proselytization, even going as far as to petition the Indian government to outlaw this problem throughout the entire country. They have taken a great interest in societal issues within India that they agree have become pressing concerns in the Hindu community. These include the banning of cow slaughter, the threat of global warming and its impact on the environment of India, and issues of temple governance and preservation. In addition, they have also striven to become more involved with inter-religious dialogue, continually working towards the goal of peace and harmony with the worlds many great religious traditions. These two particular delegations are at the forefront of inter-religious dialogue between Judaism and Hinduism. While neither delegation can claim to be the voice of every individual worldwide that describes themselves as being a follower of one of these two great traditions, they are representative of a large number of followers; hundreds of thousands for the Chief Rabbinate and hundreds of millions in the case of the HDAS. The next chapter will explain the positions which characterize Jewish and Hindu outlooks towards other religious traditions in this case. These outlooks guide and inform each delegation's approach to inter-religious dialogue and are a major reason that the dialogues were able to take place in the first place. 


\section{Chapter 3: History, Theories and Approaches in Inter-Religious Dialogue}

Dialogues among the many faith traditions that exist on our planet have been taking place for centuries. Inter-faith interaction and religious tolerance was said to abound in the Maurayan Empire during the reign of Aśoka in the $3^{\text {rd }}$ century B.C.E (Mookerji, 1962, p. 64-67). There exist writings originating during the rule of the Abbasid Caliphate in $8^{\text {th }}$ century Baghdad about a majlis (assembly) of the mutakallimun (theologists) that included Muslims, Jews, Zoroastrians, atheists, infidels, and Christians (Weinstein, p. 47, 2007). We also find examples of this inter-religious interaction in the discussions and dialogues between practitioners of Islam, Hinduism, and Sufism that became a standard occurrence in the court of Akbar the Great and his grandson Dara Shikoh in $16^{\text {th }}$ and $17^{\text {th }}$ century Mughal India (Katz, p. 150, 2000).

Despite some of these well known instances, however, historically verifiable examples of inter-religious dialogue are few and far between, scattered throughout the pages of history. Formal dialogue among the world's religious traditions, and their respective leaders, is a relatively novel concept that enters the stage of history with the 1893 World Parliament of Religions, held in Chicago, Illinois, regarded by many to be the beginning of the modern interfaith movement (McCarthy, p. 16, 2007). From this time onwards, inter-faith dialogue has become a more and more frequent occurrence. The occurrence and the frequency of these dialogues is dependent a religious tradition's approach to dialogue which is highly influenced by the position that that tradition takes towards other religions. A tradition's position is generally informed by where a tradition fits in amongst the theological categories of exclusivism, inclusivism, and pluralism. In 
the case of this Hindu-Jewish encounter, the theological category in which each tradition claimed to fall into was a major factor in the existence and progression of this dialogue.

The theological categories that I use here were first proposed by Alan Race in 1983 and, as I already briefly mentioned, include exclusivism, inclusivism, and pluralism (Knitter, 1995, p. 25). These three theological categories are used and described by many theorists. The classification system is used to reduce confusion when speaking about different religions' perspectives in their approach to dialogue. Critics charge these models as being both too rigid and too simplistic while obscuring broader varieties of perspectives and potentially predetermining the flow of theological discussion (Knitter, 1995, p. 25). As Paul Knitter notes, "Such models are limited, possibly dangerous, but also useful. They provide a workable framework that can direct, but not restrict the discussion" (1995, p. 26). The shortcomings of these categories can even be seen, to an extent, in the approach to other religious traditions as displayed by both the Chief Rabbinate and the HDAS. A forth category known as universalism, discussed only by Alan Brill, seems to emerge in this dialogue and will be explained as well. I would first like to look at the exclusivist position, which Alan Brill defines in the following manner:

'There is only one true religion'. Exclusivism states that one's own community, tradition, and encounter with God comprise the one and only exclusive truth; all other claims on encountering God are, a priori, false. There is only one way to God and salvation. Thus one religion is uniquely and supremely true and all other religions are false. Those who accept exclusivism usually affirm that other religions possess some elements of wisdom, but these religions do not teach 'the truth' of salvation, and revelation. $(2010$, p. 21)

In this manner, religious groups such as these come to view their tradition as possessing an exclusive understanding of truth not found anywhere else. Because of the very nature 
of the exclusivist position, many religious groups that fall under this category tend not to participate in inter-religious dialogue. There are, for all intensive purposes, no purely exclusivist approaches within either Hinduism or Judaism. However, there does exist Hindu and Jewish groups who could be described as taking a position which comes close to an exclusivist approach without fully embracing the category.

Followers of the Gauḍiya Vaiṣnava Hindu tradition take an approach which leans towards exclusivism. As Dr. Amaranth Chatterjee notes, "According to the tradition itself, however, Vaișnavism constitutes sānatana dharma, or the original, eternal religion of the soul. All other forms of Vedic religion must culminate in Vaișnava dharma" ("Gauḍīya vaiṣnava", 1992, p. 8). It can be gathered from this statement that practitioners of Gauḍiya Vaișnavism believe that, while accepting that others follow different religious paths, one must ultimately adopt Vaișnava worship in order to attain salvation. It must be noted, however, that not all Gauḍiya Vaiṣnavas can be characterized into the exclusivist category and some variation does exist amongst practitioners.

In Judaism, some writings of Rabbi Luria allude to an exclusive outlook on religion. In this example, Lurianic Jews can be seen as holding an exclusive status in the world compared to gentiles, or non-Jews. This exclusive outlook is demonstrated by Brill when he says:

Moshe Chaim Luzzatto, an Italian Rabbi known for his poetry, kabbalah, and ethical works, offers a systematic presentation of Lurianic Kabbalah in which the two strands, the inclusivist and the exclusivist are combined in an exclusivist framework. He accepts that gentiles are a lower level than Jews, but that they are part of the Divine order of the seventy nations. At the end of time, gentile souls exist as subservient to Jewish souls. (2010, p. 257) 
In this manner, Lurianic Judaism is not purely exclusivist as a result of the minimal role in the world that gentiles are still perceived to play. However, the elite or exclusive status that these Jews perceive themselves to have in the world is quite clear.

The second theological category I will look at is that of inclusivism. According to Brill, it can be defined as:
'One religion is best but weaker forms of religion are possible in other religions'. Inclusivism situates itself between the two extremes of exclusivism and pluralism, where one acknowledges that many communities possess their own traditions and truths, but maintains the importance of one's comprehension as culminating, subsuming, or perfecting all other truths. One's own group possesses the truth; other religious groups contain parts of the truth. They do believe, though, that truth, wisdom, and even revelation can be found in other religions. (2010, p. 22)

From the inclusivist standpoint, other religious traditions may contain varying degrees of truth and revelation, but they are not complete truths or revelations. The complete and total truth, and the subsequent salvation that comes with it, can only be guaranteed through the inclusivist's own tradition.

Within Hinduism, an inclusivistic position can be seen in the case of traditional Advaita Vendanta and the teachings of Śankara and his emphasis on a path of knowledge. The inclusivistic position that this Hindu tradition takes towards other religious practices is explained well by Thomas Hopkins in his book The Hindu Religious Tradition, which states:

As there is no means of release other than knowledge of the pure unqualified Brahman, then knowledge of a Lord with qualities cannot bring release. Devotion is a valid religious practice, and may eventually lead to true knowledge of Brahman as the devotee is led beyond the qualified Lord to the underlying real unqualified Brahman, but devotion itself without true knowledge is insufficient. (p. 120, 1971) 
Given the information in the previous quote, the supremacy of Śankara's Advaita Vendanta is clearly attested to Hopkins. It also denotes the belief that, while other types of religion are useful and provide some truth, it is only through Advaita Vedanta that one can attain release from samsara, the cycle of birth and rebirth.

A recognizable instance of Jewish inculsivism comes in some writings of Maimonides. Several of these writings acknowledge the value of other religious traditions, particularly the other Abrahamic faiths, while still affirming supremacy of his own tradition. As Maimonides said,

It is permitted to teach the commandments to Christians and draw them to our law. But it is not permitted to teach anything from it to Muslims because it is known to you about their belief that this Torah [of ours] is not from God ... and if one can convince the Christians of the correct interpretation [of Scripture], it is possible that they might return to what is good (Brill, 2010, p.104-105).

The value that Christianity holds can be seen here by the fact that they are allowed to learn from the Torah and are worth taking the time to teach. Jewish supremacy is highlighted as well in Maimonides' hope that the Christians "might return to what is good" (Brill, 2010, p. 105). As Brill states:

Maimonides accepted that Christianity and Islam are believers in the Biblical God of Israel. In the Guide of the Perplexed, Maimonides casually reiterates this point of the universality of the Biblical God and applies it to the entire civilized world. "Most people, as we see at present, agree in praising and glorifying Him, No one opposes or ignores Him, except some ignoble remnants of the nations left in the remote corners of the earth." Maimonidean inclusivism is based on a common core of monotheism as found in the Bible and the commandments firmly situated in a messianic sense of Biblical mission found in the books of Isaiah and Zephaniah. (2010, p. 104)

This inclusivist categorization of Judaism is not without its problems. This is because of the fact that Maimonides' stipulates that a tradition must be monotheistic in order to be 
acceptable. For Maimonides, while the fact remains that some traditions have a certain amount of value to them, the requirement of monotheism narrows the scope of this type of inclusivism by disregarding those who would not be classified as monotheists.

The next theological category Brill defines is pluralism:

'All major world religions have some truth'. Religious pluralism takes the position opposite to that of exclusivism, accepting that no one tradition can claim to possess the singular truth. All group's beliefs and practices are equally valid, when interpreted within their own culture. Thus, no one religion is inherently better or superior to any other major world religion. For pluralists, there may be differences in rituals and beliefs among these groups, but on the most important issues, there is great similarity. Most religions, they claim, stress love for God, and have a form of the Golden Rule. (2010, p. 21-22)

With this category, we transition towards the positions of the Jewish and Hindu religious delegations involved in this dialogue. However, although they lean towards an approach of pluralism, they blur the line between different categories along Brill's continuum.

Hinduism has long been well known for the tolerance it has generally exhibited towards other religions as well as toward the variety of belief systems found under the Hindu label itself. This tolerance is a reflection of the great religious diversity within the Indian society where Hinduism developed and the HDAS's approach toward other traditions mirrors this fact. Vivekananda, who was instrumental in the development of neo-Vedantic Hinduism, presents the position of the HDAS with a statement he made at the 1893 World Parliament of Religions:

Just as we have recognized unity by our very nature, so we must also recognize variation. We must learn that truth may be expressed in a hundred thousand ways and that each of these ways is true as far as it goes. We must learn that the same thing can be viewed from a hundred different standpoints and yet be the same thing. (Rambachan, 1989, p. 14) 
This statement seems to hint at two separate approaches to other traditions. The second line of this quote posits that neo-Vedantic Hinduism takes a pluralistic stance with its declaration that the truth religions express can come in a variety of forms that are all, to an extent, valid. This line of the quote parallels Brill's previously mentioned take on pluralism that says "all major world religions have some truth" (Brill, 2010, p. 21-22). In the last line, however, Vivekananda says essentially that all traditions adhere to the same truth, but just express it differently. It is with this statement that a universalist approach towards other religions can be seen. Brill defines universalism as:

'The truth is One'. Universalism is midpoint between inclusivism and pluralism, where one acknowledges that the universal truths of God, soul, intellect, and ethics have been made available by God to all people. This is usually a God centered approach, in which the theism transcends the other elements of religion. (2010, p. 22)

This quote diverges from the pluralist position defined by Brill which does not claim all traditions are preaching the same thing in different ways, but rather that traditions have different truths which are all equal with one another. Like Vivekanada, the HDAS seems to express a position the straddles the line between universalism and pluralism.

The stance of the HDAS is reinforced by several affirmations made at the first HinduJewish Leadership Summit which proclaims the Hindu delegation's belief not to "seek to proselytize, nor undermine or replace in any way the religious identities of other faith" communities (The Declaration of Mutual, 2007). This statement demonstrates a perceived acceptance of other religious traditions without any preexisting condition, which indicates pluralism. The words of Swami Madhav Priyadas, however, seem to embrace a more universalist position towards the Jewish delegation when he stated, "Despite the differences we are one expression, of one principle, like the thread, having 
different beads in the rosary, but ultimately it is one" $(2008$, p. 36). Here it is implied that these two traditions are different, but ultimately are both God centered traditions that lead to the existence of universal truths, ethics, and intellect present within each sacred tradition.

Shifting to the Chief Rabbinate's position, they certainly do not take an exclusivist perspective towards other religious traditions, but beyond this the theological category they fall into can be difficult to place. Being that they are orthodox in practice, they can be observed to possess some exclusivist or inclusivist characteristics and judgments with regards to views on Judaic theology and their outlook towards other religious traditions. Because of this fact, I would not label them pure pluralists as defined earlier; although in comparing the views of the Jewish delegation before and after the summits, one can note a clear progression in this direction. At the meeting in Delhi, Rabbi Daniel Sperber, a professor at Bar Ilan University and Chairman of the Israeli Chief Rabbinate's Commission for Inter-religious dialogue, made a clear reference to a pluralistic approach when he said,

The same sunset can be seen by two people and each will give an accurate impression, which although different, will be truthful. Similarly, there are multiple truths of that which is outside of us. God creates everything that is not identical. We see truths in our own subjective fashion. There is no single, holistic truth; each person has his own truth (Sperber, 2007b).

This is unquestionably a pluralist position because of Sperber's recognition that there is no one truth and that everybody possesses a truth unique to their practice. Sperber also says that, "Just as a hammer when it strikes an anvil send off many sparks, each of the sparks is an interpretation" (2007a, p. 30). In the metaphor Sperber uses, the hammer represents truth and the sparks represent different, yet equally valid, religious 
interpretations of that truth. The Jewish delegation does not totally embrace Sperber's notion though. As Rabbi David Rosen, the Director of the American Jewish Committee's Department for Interreligious Affairs and the special advisor to the Chief Rabbinate of Israel on inter-religious affairs (Promislow, $\mathrm{n} / \mathrm{d}$ ), noted at the first Hindu-Jewish Leadership Summit in Delhi: "While we affirm the freedom of religion, there must be limits to pluralism. The limits are met, above all, wherever human dignity is denied, whenever a religious approach denies dignity to another" (Rosen, 2007b). When taken at face value, this declaration leads one to classify the Jewish delegation as "ethical pluralists." The form of ethical pluralism I refer to consists of a universal ethic independent from revelation combined with pluralism based on the multiplicity of human subjectivity and was developed by Haifa University Professor Raphael Jospe (Brill, 2010, p. 207). What is absent from Rabbi Rosen's quote is the premise that the Chief Rabbinate's acceptance of the freedom of religion requires a tradition to be devoid of blasphemy and idolatry in addition to being ethical.

Traditionally, the recognition by an orthodox Jewish faction of another religious tradition as being acceptable to follow is based on that tradition's adherence to the seven Noahide laws. The Seven Noahide mitzvoth (commandments), as articulated in rabbinic literature, consist of the following: establishing courts of justice, practicing sexual morality, and the avoiding of bloodshed, robbery, tearing the limb from a living animal, idolatry, and blasphemy (Katz, 1997, p. 35). The first five laws deal with ethical behavior, but the last two laws are matters of doctrine and therefore are separate from ethical behavior. In using the Noahide laws to determine acceptable religious practice, therefore, the Chief Rabbinate requires a tradition to be monotheistic in addition to being 
ethical. The comment by Rabbi Sperber and the necessity of adherence to the Noahide laws, demonstrates a position by the Chief Rabbinate that seems to exhibit characteristics of both pluralism as well as inclusivism. They are pluralistic in the sense that the practice of other traditions can be acceptable and as equally effective in connecting with the divine as their own tradition. This point is made clearer at the summits by Rabbi Daniel Sperber when he states, "We [the Jews] are not a religion of proselytizers. In our views, all people of all beliefs and faiths should share things, including their own way of seeing things" (Sperber, 2007a).

They are also inclusive in some respects as well because as Rabbi Rosen said "there must be limits to pluralism." Although the practice of other traditions can be completely acceptable in the eyes of the Chief Rabbinate, it does not come without a stipulation. That stipulation is the obedience to the Noahide laws, which requires the adoption of some of the most basic tenants of Judaism. By requiring other traditions to adopt these laws in order to be "acceptable," they seem to imply the superiority of certain aspects of their own understanding of truth and therefore identify with the inclusivist position as well.

Despite the ambiguity that exists in the positions of the HDAS and the Chief Rabbinate towards other traditions, an important commonality exists that connects these approaches, namely, a deep conviction to attempt to celebrate and validate other traditions equitably. The important role their positions towards other religious traditions played in this dialogue can now be seen. The pluralist and universalist informed positions taken towards other faith systems by both delegations, produced a dialogue-friendly atmosphere by which this encounter was made possible. The further importance of each 
delegations position towards other traditions in this dialogue is detailed in the analysis chapter with regards to the progression of the meetings, the level of understanding that resulted, and the developments that came out of them.

\section{Chapter 4: Methods-Adventures in the Field!}

The day is May 13, 2010. I was spending my first day in Delhi. I had gotten in quite late the night before and only was able to rest for about six hours. In the morning I left Delhi's YWCA for a quick tour of the city from my newly acquainted friend, Mr. Suren Singh, who then took me to the city's train station. Exiting his car, thanking my new friend for his great hospitality and care, I slowly "hiked" into the station. It was a sight for sore eyes, like nothing I have witnessed. It was the hottest time of the year which gave way to temperatures that were in excess of 110 degrees Fahrenheit, the sun was mercilessly beating down through the hazy air with not a cloud in sight and here I was. I stood in the midst of thousands and thousands of people running, clamoring, and pushing to get to one of the over 15 trains in waiting to go to various destinations across India. I was making my way north for my first interview to the Hindu holy city of Haridwar, on the banks of the Mother Ganges where the Himalayan foothills meet the great plains. As I cleared the dust from a vacant spot on some stairs, waiting for my train to arrive, I gazed upon the crowds of people making their daily commutes. In recollecting the overwhelming number of individuals and the shear chaotic atmosphere that characterized at the station, I thought to myself that this was a sight that could not be 
viewed anywhere else in the world. This experience at the station was my first impression of India's timeless culture.

The previously describe experience is ethnography and it is the method by which I carried out much of the research for my study. Its use was crucial in gathering information for my topic being that very little has been written of it for it is such a recent occurrence. My love and interest for Hindu and Jewish culture dates back a bit further, however. I have always had a great interest in exotic cultures and religions growing up. Throughout my childhood and adolescence I remember consistently reading books about far away lands that I dreamed of one day visiting. Entering my undergraduate studies, I made the study of religion and culture a lifelong endeavor, focusing on anthropology and religious studies. It was here that I met my first mentor, Dr. Steven Bonta of Penn State University. He was my Spanish professor and through a random sequence of events I had come to learn that he was a South Asianist whose real passion was for Indian language. At this point he offered to teach me Singhalese, the native tongue of the island nation of Sri Lanka. During my language studies, I became acquainted with the wonders of India in listening to stories of my mentor's graduate research there. The diversity of striking and unfamiliar practices found throughout the breadth of this ancient land then became the object of my intellectual curiosities which I pursue today.

Judaism has always been more of a personal issue. I had never intended my personal journey through the Jewish faith and my involvement with the Jewish community to become a part my academic endeavors. It was not until spring of my junior year in college when my pursuit of Judaism would become an integral part of my 
academic study. I took a class entitled "Jewish Communities" with Dr. Alan Benjamin. Prior to this, I had never before realized the contemporary existence of "exotic" Jewish communities around the world. I found a particular fascination with a Jewish community on the island of Djerba, off the coast of Tunisia. It was at this point that I knew I needed to find a way to combine my passion for Hinduism and India with my new found interest in exotic Jewish communities. I found that there would be no better way to do this than to study Hindu-Jewish relations and the Jews of India, and no better person to study them under than Dr. Nathan Katz of Florida International University.

With my academic study set and my mentor guiding the way, I wanted to do research and write a thesis that would make a new and original contribution to the field. Dr. Katz brought the Hindu-Jewish leadership summits to my attention, noting the impact these meetings could have on the future international relations as well as the fact that they had never been studied in an academic manner. My research topic was set and now began the roughly nine month process of making relevant contacts and gaining access to the field. This process began in September of 2009 when Dr. Katz put me in touch with the Mr. Bawa Jain of the World Council of Religious leaders My preparation during the nine months preceding my field work was rather intensive. Reading and writing consumed the majority of the time for this preparation. I became well acquainted with the history of Jewish-Hindu relations, the background of the two major representative groups at the meeting, and with theories and examples in the field of inter-faith dialogue. I also become quite familiar with the summit reports from both the Delhi and the Jerusalem meetings which became my most invaluable resource after the interviews I initiated in India and Israel. These interviews would not have been 
possible, however, without Mr. Jain whom I was put in touch with by Nathan Katz. He became my "gate keeper;" my means of gaining access to the field and an indispensible figure for connecting with the dialogue participants in both India and Israel; indeed my research would not have been possible without him. After a series of e-mail correspondences and phone conferences with Mr. Jain, I was honored to be able to make a trip to New York City to engage with him in a face to face meeting. After nearly two and a half hours of enlightening conversation with Mr. Jain, he agreed to support and guide me in my research. In our conversation, we discovered our personal interests in the Hindu-Jewish relationship to be quite in sync; that these encounters were something of great importance, that we both see potential in and feel quite passionate about. It was from this meeting that I made contacts with the religious leaders and academics that I interviewed, there by making my "entrance" into the field.

The next four months were reserved for continued education about the background of the subject I was studying. I went to work fast making contacts with those Mr. Jain and I had decided were most important to interview. In addition, I frantically worked to make travel arrangements which would coincide with time frames in which my interviewees were able to meet. My travels took me around the globe. I began my journey in New York City on the way to Delhi. Once here, contact with the interviewees took all around the mighty subcontinent from the foothills of the Himalayas in Rishikesh, to the ancient ports of Cochin on the Malabar Coast, finally ending in the most modern metropolis in all of India, Mumbai. From here, I made my way to Jerusalem, Judaism's most sacred city and the location where all my interviews with members of the Jewish delegation took place. 
The settings for my interviews may be the most varied aspect in all my research. I found myself in the most intriguing of places. In India, all my interviews were done within the confines of an ashram. The diversity in these settings was phenomenal. They ranged from crowded, devotee filled ashrams in the forested foothills of the Himalayas and jungles of western Tamil Nadu to a desolate, uncongested ashram on the dry, dusty outskirts of the Gujarati city of Rajkot, to an ashram located in amidst the hustle and bustle of Mumbai. In Jerusalem, my interviews took on a slightly different appearance. Located in exclusively urban settings, I found myself in the personal offices of all those I whom I interviewed in Israel. The first was located in a rather ordinary looking office building in the heart of the New City, the second on the campus of Hebrew University, and the third was located in the office of the individual's home which was nestled between narrow pathways of the Jewish Quarter in the Old City. As can be gathered from this information, the majority of these interviews were done individually and in person. For those participants with whom I could not meet in person, the interview process was conducted via e-mail by asking a series of questions which were answered and sent back to me to record.

The interviews themselves consisted of speaking with religious leaders (i.e. swamis and rabbis) as well as other individuals involved with of each respective delegation, including academics and observers, who were present at one or more of the summits and who combined to form the delegations. Including both summits, there were a total of twenty members [appendices A, B, and C] of the labeled "Jewish delegation", three of whom I interviewed. Of the thirty-seven members [appendices D and E] of the labeled "Hindu delegation," I spoke with seven. Keep in mind that while the difference 
in the number of the delegation members that I interviewed compared with the total number creates a sizable gap, many of these delegates played minor roles in the meetings with little or no speaking parts. Although there are many participants whom I was not able to interview, I was able to interview the two leading speakers for the Jewish delegation that were present at both meetings, Rabbis David Rosen and Daniel Sperber, and the two leading speaker for the Hindu delegation at the Jerusalem meeting, Swamis Adveshvaranand Giri and Parmatmananda. I spoke with these leaders in addition to speaking with the individual who organized and mediated these summits, Mr. Bawa Jain. At the Delhi meeting, all Hindu leaders spoke in what I have judged to be equal mounts according to my analysis of the summit reports.

My initial approach towards the interview process was very Naturalist. I went to my first interviews with some general question prompts while allowing for the interviewee to dictate where the conversation was going. As I completed more and more interviews, I took notice of common themes and what individuals tended to focus on as important in this series of meetings. By the culmination of the interview process, I had a fairly concrete set of questions that I posed to my interviewees while still allowing for a natural flow of conversation to take place and interviewees to determine the direction of the conversation. It was from these conversations, therefore, that I teased out four major themes that support the existence of new, meaningful developments between the two traditions. These themes are discussed and analyzed in the next chapter and include the following:

- The "newness" of the dialogue

- Cultural threats of secularization and terrorism 
- The issue of proselytization

- Self-defining history, symbols, and concepts of the divine

\section{Chapter 5: Hot Topics of Discussion}

The summits had several main areas of interest which leaders from both sides chose to discuss. These areas were chronicled and described in the printed "summit reports" of which one was printed for each the Delhi and the Jerusalem meetings. The main topics of discussion at the summits included, but were not limited too: (1) Jewish and Hindu concepts of the divine, (2) the anti-conversion efforts both religions endorse in order to preserve culture and tradition, and (3) the understanding of Aryan symbols, particularly the swastika, and their traditional meanings. By reading through discussion topics and taking note of what my interviewees focused their reflections on, I have identified four pertinent themes that will serve to demonstrate the novel and significant developments for both traditions found which emerge from this inter-religious dialogue.

1. The first is the newness of the dialogue itself. This is the first time in recorded history that two "non-universal" religions have come together for a dialogue like this without the meditation of one or more traditions that are not "non-universal".

2. The second deals with shared threats that both respective traditions and cultures are dealing with in the modern age. The focus here is on the challenges of "secularization" as well as "terrorism"- forces that continue to endanger both traditions. A unique feature that both these traditions share is that they are integrated into entire 
ways of life which can not be easily compartmentalized; these religions become indistinguishable from other parts of the culture. They both developed as "lived" traditions where religion is not compartmentalized as it is in many secular and Western cultures. Both traditions' histories over the last two centuries have been heavily targeted by terrorist activity. Secularization, as well as terrorism, therefore, poses very real threats to each of these respective cultures.

3. The third important theme also relates to the threatening of tradition, but in the form of proselytization by Christians and Muslims. This is a threat that had plagued Jewish communities for centuries up until the last few decades, and is currently considered to still be a serious concern of the HDAS, for Hindus in India are described as being unknowingly attacked and converted.

4. The forth and final theme focused on here deals with understanding and supporting one another's views of self-defined history and self-understanding. Foreigners and outsiders have at times misrepresented Hindu and Jewish practice, history and symbolism for centuries. Because of this, inaccurate information is passed down through the generations resulting in misunderstandings and misconceptions about one another. A major area that falls under self-understanding that I will discuss here is the issue of Hinduism as a monotheistic tradition.

It has been the age-old perception among many Orthodox Jews, including the Chief Rabbinate of Israel, that Hindus are definitively idolaters or polytheists. Had this been fact, it would have restricted Jews from having any kind of extensive or meaningful relationship with Hindus, if at all, due to precepts of Halacha, or Jewish law. The 
incentive of proper understanding of this premise on both sides, therefore, becomes of the utmost importance and a major theme in these dialogues.

\section{A New Type of Dialogue: A 'Non-Universal' Meeting With Universal Implications}

From the very onset, the proposed meetings between the Jewish and Hindu delegations were seen by participants as a landmark: history was being made as a new type of Hindu-Jewish inter-faith dialogue was on the verge of taking place. For the first time in recorded history, two "non-universal" religious traditions were meeting formally. Therefore, the occurrence of this meeting is a demonstration of a new development in itself. The characterization of Judaism and Hinduism as "non-universal" religions had a significant effect on the structure of the dialogue. One aspect of the two faiths that defines them as "non-universal" religions is that Judaism and Hinduism are traditions that are deeply linked, historically and culturally, to a piece of geography and an ethnic people. For the Jewish people this land is Israel and for the Hindus, India. The connection each religion has to these two factors of land and people is of the utmost importance in matters of how they define themselves. This goes contrast to a "universal" tradition, such as Christianity, which has no deep rooted connection to a specific ethnic group or piece of land the way Jewish and Hindu traditions do.

The absence of an initiative to proselytize is also a major point of connection between these two traditions. In fact, proselytization is seen as a threat to both traditions, as will be detailed in a later chapter. There is no standard conversion process for an individual who wants to be a member of the Hindu community and an individual's 
recognition within a any given community could vary, but in most Hindu traditions they would not be recognized as a Hindu because of its strong tie with ethnicity. Ethnicity does not present as much of an issue in Judaism, as there does exist a conversion process. For an outsider who wants to become a member of this religion, it is typically not an easy process, especially within Orthodox circles. It is not uncommon for a rabbi to deny an individual's conversion request several times before conceding to convert an individual. Rabbis typically first try to convince a potential convert that conversion is not necessary and that the Noahide laws are all that need be followed for a non-Jew. The Jewish position on the issue of conversion was definitively stated by Rabbi Rosen at the first summit:

When someone comes to the Rabbinic Court and says "I want to be with you," we are obliged to say that they are not required to convert to find the fullness of their soul. The person is already acceptable in the eyes of the Almighty. We are obliged to tell the person that they are loved and acceptable as they are so long as they follow the basic moral codes. (2007c, p. 41)

For Jews, the absence of an imperative to convert comes out of reasons rooted deep in their history. This understanding of a non-conversion effort emerges out of a tradition which is culturally particular, historically specific, and based on particular experiences, therefore making it senseless to expect or require outsiders to covert to or follow it (Rosen, personal communication, 6/24/2010). The same understanding would follow for the Hindu tradition as well, which is also culturally particular, historically specific, and based on particular experiences

Another unique link in the dialogue between the two delegations comes with reference to the popular religious distinction between "orthodoxy" and "orthopraxy" or 
"right teaching vs. right practice" (Hopkins, 1971, p. 73). Orthodox Judaism and neoVedantic Hinduism are most commonly referred to as "lived" religions because of the traditional emphasis on particular ritual action as the central element of the religions. It is very important to note, however, that these traditions cannot be defined totally within the borders of either orthodoxy or orthopraxy. Both the Hindu and Judaic traditions inherently exhibit characteristics of both these categories through a variety of aspects found in their theologies. Gustavo Gutierrez makes a noteworthy assessment regarding orthodoxy and orthopraxy: "Orthodoxy and orthopraxis are related each to the other; each feeds the other. If we limit ourselves to one, we reject both" $(1988$, p. 180). This premise of "orthodoxy vs. orthopraxy" is likewise highlighted by Katz when he stated, "The Hindu-Jewish dialogue is about the absolute and practices which lead to the absolute. Even as I maintain that it is a mistake to focus upon orthodoxy to the neglect of orthopraxy, so too is it a mistake to neglect doctrines and mysticism entirely" (1997, p. 37).

The notions of "right belief vs. right practice" become a relevant point in our discussion regarding the newness of the Hindu-Jewish dialogue, insofar as there is a "natural alliance" that is formed as a result of the orthopraxic nature found in both religions. That being said, I believe it is important to describe where the pattern lies within each of these respective traditions as far as 'orthopraxy' and 'orthodoxy' are concerned, while noting specific reasons for labeling each tradition dominantly as one or the other. Furthermore, it should be recognized that this distinction has a relevant part to play in the inter-faith dialogue process between the Jewish and Hindu faiths. In describing characteristics of Hindu-Jewish dialogue, Nathan Katz notes that: 
An overemphasis on the "absolute" (as a metaphysic or as an experience) tends to predetermine the outcome of interreligious dialogues, often distorting the religious traditions represented. Underlying this search for the absolute is the tacitly Christian assumption which values orthodoxy over orthopraxy. Most Hinduisms and most Judaisms, on the contrary, value practice over doctrine, and the primacy of orthopraxy over orthodoxy. (Katz, 1997, p. 33)

Keeping in mind Katz's remark about the Christianity, lets look at an which values orthodoxy over orthopraxy. Christianity holds central in its theology the crucial importance that belief in Christ as savior of mankind, the sine qua non for determining an individual's salvation. The centrality placed on this belief is the main reason for classifying Christianity under the 'orthodoxy' label as opposed to 'orthopraxy'. In referring to that which continues to inspire much of Protestant Christianity, $20^{\text {th }}$ century theologian Karl Barth makes the claim that we are saved "by faith alone" in Jesus Christ through revelation in holy scripture (Knitter, 2002, p. 24-25,). This is not to say that all Christians take this approach. The dichotomy is explained in Peter Kreeft's book on Catholic catechism when he states, "The controversy that primarily provoked the Protestant Reformation was the controversy about faith and works. Luther taught that we are justified and forgiven by faith alone, while the church held that good works were also necessary for salvation" (Kreeft, 2001, p.126). Today some "inclusivist" traditions, such as Roman Catholicism, hold the value of works, actions, and rituals of equal importance with belief in Christ. In any case, the fact of the centrality of the belief in Christ as universal savior in Christian religion remains.

The labeling of Judaism as an "orthopraxis" religious tradition as opposed to "orthodoxy" relies heavily on the dominance of Halacha or the Jewish legal system in Judaic religious life. There are 613 commandments derived from the Torah that bring 
a central focus on the way the individual lives his or her life with no reference to salvation. As Rabbi Alfred Cohen states, "For the 613 commandments in the Torah, there is no mention of any reward" $(1984$, p. 308). At the second meeting of the Hindu-Jewish Leadership Summits, Rabbi Daniel Sperber furthers the notion of Halacha, particularly the Sabbath, when he made the following statement:

In our tradition, "Halacha", the Jewish Religious Law, which comes from the word go, means it does not stay in one place and continue to develop, and you go with it from generation to generation. Our Halacha deems the rest of the Sabbath as a major component in our religion that according to the rabbinic traditions is the basis of all the other Commandments of God. You may know that we have 613 commandments, do and do not do, in the Bible, in the five books of Moses. Every observant Jew is supposed to abide by them (2008a, p23).

One can see the importance here that Sperber ascribes to the commandments, to do or to not do, to act or to not act. The focus on action is further divulged when he said:

We [Judaism] have very little in the area of dogma. There are two basic concepts, the concept of intention, thought intention and the concept of deed action. In Hebrew we say "Kavana ne maase". In Judaism there is no doubt that action plays a greater role, more dominant role than that of intention. (2008c, p. 40)

The orthopraxic nature of Judaism is therefore demonstrated in it's downplay of dogma in favor of a focus on action.

Orthopraxy in Hinduism is highlighted by the concept of dharma. This dharma allows men to live in society and work toward the distant, but desirable, goal of mokśa. It dictates how humanity should act and it includes all actions by which men define and express their place in the cosmos (Hopkins, 1971, p.73). Referring to priestly social and ritual standards, Thomas Hopkins notes that:

The details of these standards had been worked out from the time of the Brāmhanas onward, but in the period after $500 \mathrm{BCE}$ there was a great increase in the number of texts dealing with duties of men in everyday life. 
The result was a large body of Brahmanical teachings on social as well as ritual responsibilities. These responsibilities were collectively called dharma, "that which is established", or in more specific terms, "what men ought to do". (Hopkins, 1971, p. 73)

Dharma was one of the most fundamental topics of discussion coming from the Hindu delegation at the summits. The relation dharma shares with the Halacha in the orthopraxic realm was voiced at the second summit when Swami Parmatmananda, secretary of the HDAS, explained, "Though today it [dharma] has been limited to religion or a belief system, but primarily Dharma means a duty based life. Indian culture, Indian upbringing always emphasized on duties rather than the rights" (2008c, p. 45). The concept of dharma is so important in the Hindu religious tradition that in some cases the Hindu delegation used the term interchangeably with the name of their religion. This fact was exemplified by Swami Vishveshvarananda: "Another name for this old religion [Hinduism] is 'Santana Dharma'" (2007, p. 27).

Dietary laws are a relevant aspect of both Jewish and Hindu practice. The dietary laws that both traditions impose on their practitioners are a prime example of their nature as orthopraxis centered religions. This is orthopraxic because, in the eyes of many outsiders, everyday diet expands well beyond the realm of what would commonly be considered a "religious" concept. The existence of dietary laws in both religions opens another lane of dialogue by which each tradition could potentially connect with the other. It is a line of thought that is neither available nor important when dialoguing with a Christian faction. As Katz notes, "While Hindu and Jewish dietary codes do not coincide, they do overlap, and these are areas in which communication and cooperation can be developed" (1997, p. 38). 
The concepts of dharma and Halacha and the existence of strict dietary laws all play into the notion of a "lived" religion which is commonly associated with orthopraxis religions. As non-compartmentalized traditions that are entire ways of life, everyday activities from eating to bathing to simply waking up in the morning all take place within what can be defined as a religious framework. For individuals of these traditions the boundary between "religious" and "non-religiously" related activities is extremely blurred if not completely non-existent in many cases. Dr. L.M Singhvi, a constitutional expert and former member of the Indian parliament, stated that "Dharma is that which sustains and keeps us together. Like us Hindus, the Jews unite with us in their adherence to righteous living" (2007, p. 23). He depicts the vital importance of dharma to the Hindu religion while affirming how this concept ties Hindu practice with that of the Jews. Rabbi David Rosen verified this one of a kind bond:

There are many commandments, which tell us that to live a Jewish life is to be alive to the consciousness. It is a way in which the language, culture, and religion are intertwined. This is not found anywhere, except in Hindu culture, where the religious culture and society are similarly connected. (2007, p. 25)

In this respect, the shared orthopraxic natures exhibited by these two traditions, in conjunction with "non-universality" and an absence of conversion efforts, demonstrates a new and significant development when placed in the context of an inter-faith dialogue. 


\section{Cultural Threats: The Challenge of Secularization \& Terrorism}

It is the early morning on a summer day during late June in Jerusalem. I step out of my place of lodging during my stay in Jerusalem which was called The Austrian Hospice of the Holy Family. It is an Austrian run, Roman Catholic pilgrim hospice located in the heart of the Muslim Quarter of Old City Jerusalem. The building itself dates back to around the mid $19^{\text {th }}$ century and is steeped in its own history as well as the history of all that has taken place here since in was originally built as a protective enclave for Catholic and Ashkenazic Jewish pilgrims ("Historical information concerning," ). I am on my way to conduct my first interview in Israel at the office of Rabbi David Rosen. In light of the hot and sunny conditions that graced Jerusalem that day, I decided to walk the roughly 25 minute journey to Rabbi Rosen's office. The journey took me through the crowded, narrow corridors of the Old City, over Roman-era cobble stone paths. As I traveled through the labyrinth of roads that criss-cross their way through the various quarters of the Old City, I become engulfed with smells of falafel, frankincense, and, at times, even raw sewage while hearing the accents of no less than a half dozen different languages at any given time. I graciously take in the sights and sounds of this part of the city and the nostalgic feeling it causes to rise in one.

I eventually make it out of the Old City at its west side through the Jaffa Gate, towards the Rabbi's office in the new city, and I notice something. I notice that, despite its richly deep history that dates back thousands of years and sheer beauty of the city itself, Jerusalem is a highly modern city, quite reminiscent of a typical city back in home in the United States. Now, I am by no means naive to the worldwide trend of modernity 
and globalization, however, in thinking of Jerusalem before I arrived, I did not picture anything similar to the urban centers scattered throughout the US. I was quite surprised to find typical street signs, restaurants, schools, and even American automobiles! I then realized that even here, in one of the oldest, most sacred city's on the planet, where some of the most solemn chapters of religious history ever have taken place, there was no immunity from modernity and globalization. The signifiers of modernity were all over for one to see, and it came at no surprise with the summits when I noted secularism and its effects on the two traditions was one of the issues discussed.

The threat of secularization was a common theme found in both the published summit reports as well as my individual interviews. It is a problem that, because of globalization, and the rise of modernity, is nearly impossible to escape the effects of. As Rabbi Rosen remarked in referring to these Jewish and Hindu traditions, "There is a threat from secular worlds. To commit to tradition in a secular world is extremely difficult" (personal communication, June 24, 2010). It continually is making its lasting mark on traditional cultures and religious practice across the globe, but for Orthodox Judaism and Neo-Vedantic Hinduism secularism proves to be a double edge sword. This is because the previously described notion of these two traditions not just being "religions," but entire cultures, identities, and ways of life. These truly ancient religions carry with them political theories, medical practices, astrology, aesthetics, philosophy, dietary laws, science - virtually everything. Secularism is in itself a competing culture complete in some senses, with its own political systems, institutions of higher learning, values and, maybe most notably, a diminution of the domains of religious traditions. Many of the world's other religious traditions, although by no means completely free 
from the threat of secularism, nonetheless can be compartmentalized and practiced in conjunction with a secular culture more readily; something that can not be easily done within the Jewish and Hindu traditions described above.

My interviewees emphasized that the secular threat is one that cannot and must not be overlooked as a challenge facing both of these religious groups. The relevance of this threat was underscored by Rabbi Rosen when he stated:

Now we get into challenges that are probably the biggest challenge of all time, the modern age in which we live. Because the pressures that we have faced historically have paradoxically, even in our [the Jews] suffering and difficulties in a way served to protect us against precisely the world that was antagonistic towards us. Today, if you like, the challenges, if I may use the metaphor, my colleagues will understand from our biblical tradition, it is the "kiss of Evil", it is opportunity that we have and the openness that threatens our ability to be able not only to survive but to be creative. This is the real challenge before us in our time. (2008, p. 39)

Similarly, Rabbi Daniel Sperber also notes that, "There is a challenge that is facing us from the newly emergent way of thought that developed in these modern times. These are complex challenges" $(2008 \mathrm{c}$, p. 41$)$. The influx of these ideas and this mode of thought has been a gradual, but consistent process. It comes from a variety of different sources including the media, the internet, television, and personal travel just to name a few. The reality of this issue for the Jewish world can be seen in the description I gave of my walk to Rabbi Rosen's office, notably, in the contrast between the Old City and New City of Jerusalem; it was visible with the lack of modesty in the way people dressed, in the design of the street buildings, and in the advertisements for European and American brand names found on nearly every street.

My experience in India was similar and, although I spent a good deal of time in rural areas, I did not escape the affects of modernization and secularization in this rapidly 
progressing nation. Despite the fact that India is still considered a developing country by many, secularization and modernity abound. Western style coffee shops, restaurants, and grocery stores could be found in several of the country's many urban areas that I visited. The skyscrapers of Mumbai were among some of the most impressive I have ever seen and the efficiency of the city's train system is comparable to metro systems that are found in the United States. Modern ideas and secular ways of thought infiltrate and spread through the Hindu tradition in much the same way they do the Jewish. As Rabbi Rosen noted, "The big challenge in India today is the loss of identity" (personal communication, June 22, 2010). The level of penetration of these ideas is evident throughout India, especially in cities like Calcutta, Mumbai and in Bangalore, India's IT capital. The booming technology phenomenon has been scourge on Hindu tradition as far as the spread of secularism goes. As Rabbi Sperber notes:

When you have a city like Bangalore, which is a high-tech city, which is sort of 'Silicon Valley' of India, has an enormous concentration of highly intellectual people. Many or most have been trained probably in Europe or the United States, come back with Western ideas. It's probably quite difficult to sort of get back in the tradition of Hinduism. So this they [the Hindu delegation] see as a challenge. (personal communication, $7 / 11 / 2010)$

Sperber indicates here that people like this, those that go away and experience the modern culture of the West first hand, come back to India and further progress the process of secularization there. Swami Adveshvaranand Giri, a major leader of the Hindu delegation at the second summit in Jerusalem, was sure to mention the destruction of secularism when I spoke with him. He referred to our current time being the "age of consumerism" and that the materialistic mindset aids in driving adoption of a secular culture (personal communication, 5/14/2010). 
We can plainly see the ways in which secularization affects a culture, and all that is a part of that culture through the modernization of cities, transportation, and, one of the most noticeable, the lack of modesty in the style of dress. There are even greater concerns with relation to secularization, however. These are concerns that tend not to be material in nature and may not be so obvious to an individual from outside the affected culture. One of the most pressing areas of concern here lies in the realm of ethics: "There is a need on the part of our youth to fill the void which has been created in their heart due to an education which is ultra rationalistic, de-ethicized and without serious, clear priorities in life," (2008c, p. 43) Sperber notes. Swami Parmatmananda spoke in very similar words when he said, "In a real sense, our country [India] is secular, so our education system does not have any inbuilt mechanism to educate our children about our culture, tradition and religion" (Parmatmananda, 2008c, p. 43).

Secular culture's destructive effect on the ethical systems traditionally found in both Judaism and Hinduism can be seen in the compromise of the most sacred values of these two traditions. One instance can be seen in the breakdown of the family unit and the bond between man and woman, created through the sacred act of a religious marriage, of which the source of the family unit rests (Sperber, 2008c, p. 41). Moral and ethical behavior in sexual relationships is a value to be viewed with the utmost respect, notes Sperber. He goes onto describe the nature of this type of relationship: "Sexual relationships, one man and one woman loyal to each other, married in a covenant blessed by God" (2008a). Immodest dress, casual sex with multiple partners, sex before marriage, and civil marriage, which are seemingly acceptable practices in secular society all work to contribute to this breakdown of traditional Hindu and Jewish values. Another 
instance can be found in the practice of legalized abortion and in it, the desecration of each tradition's most sacred value of preserving the sanctity of life. These are just a couple of the ways in which the morality and ethical conduct that is so central to Orthodox Judaism and neo-Vedantic Hinduism is being disregarded and fading away in each culture. These are serious issues which attack the very core of everything these two traditions stand for and are just a couple of the many issues that are increasingly threatening the two traditions. Sperber continues by referring to a strategy to combat the affect secularism is having on the education of the youth of this generation:

I know it is a tremendous challenge, and it is a challenge every educator faces. We have to go about it by relearning the original texts, by learning them in the language in which they were written, by sharing the depth and the richness of the heritage of each of our traditions, whether it is Sanskrit, or Hebrew or Hebraic tradition (Sperber, 2008c, p. 44).

Sperber suggests here that a potential answer for this problem lies in educating the youth in each respective culture's traditional language. This would allow one the means to reconnect with their tradition and ethical system, the bases of which originate in ancient texts such as the Torah for Jews and the Vedas for Hindus.

Therefore, the manner in which secularism affects these Hindus and Jews is different from the way it affects most other religions where secularism is more compatible with their practice and the threat not as pressing. Being that both traditions are burdened with the same impending threat, an avenue of connection, discussion, and mutual concern for one another has been able to develop as a result. Referring back to my meeting with Rosen, he voiced that both groups need to reflect much more [on the secular threat], noting that the Jewish community has more experience to reflect on (personal communication, June 22, 2010). It is this experience that has provided some 
support in the link between the two delegations. The Hindus hope to learn from the Jews reflected experiences. Efforts to solve this rapidly encroaching problem are a part of a bridge that has been built between these two delegations which hope to mutually benefit one another in their respective fights against the imposing threat of secularization. The attention and sincerity with which this subject has been, and is, dealt with by both religious factions, demonstrates its importance within the framework of the Hindu-Jewish dialogue. The threat of secularism, therefore, will not play the same role in dialogue involving one or more traditions that can be compartmentalized in the face of secularism and where culture and religion are separate, distinguishable phenomenon from one another.

Dialogue participants felt that while secularism gradually, and seemingly silently, continues to progress as a major threat to both traditions, it is the threat of terrorism that grabs headlines and is most realizable to the general populace. Like the secularist threat, terrorism does affect many others around the globe in addition to the Jews of Israel and the Hindus of India, but the threat to these two factions is again different. The majority of terrorism against the two traditions has been associated with the actions of Islamic jihadist organizations that, over the last several decades, have had a history of violent conflict with the two cultures. The frequency with which terrorist acts have been, and are, present against Jews in Israel and Hindus in India are therefore quite high, creating a serious cultural threat. The tumultuous and violent feelings brought about by the IsraeliPalestinian morass for the Jews, and by the Indian-Pakistani conflict for the Hindus, no doubt plays a central role in each tradition`s struggle against terrorism. Unfortunately, it 
is this shared historical experience over the last several decades that creates an unwanted area of relation that has become a major issue for both religions.

In December of 2010, a terrorist strike took place in Hinduism's holiest city of Varanasi, where an explosive device killed a two-year-old child, while injuring about twenty-five others (Singh, 2010). Responsibility for this attack was claimed by the radical Islamic group known as Indian Mujahideen which promised more attacks and made an announcement via e-mail saying, "Indian Mujahideen attribute (sic) this attack to the 6th of December [anniversary Babri Masjid demolition] that will haunt your nation of world's 'Greatest DemoNcracy (sic)'” (HT Correspondent, 2010).

In September of 2004, the southern Israeli city of Beersheba unfortunately suffered a similar attack by the Islamic terrorist organization known as Hamas, when two suicide bombers detonated themselves on crowded buses (King; Zer, 2001). The graphic and violent nature of these attacks are noted by the authors who mention that, "At least 16 passengers were killed and nearly 100 were injured by the blasts, which scattered charred metal, glass shards and body parts across a palm-lined boulevard" (King; Zer, 2001).

These are just two of the innumerable instances of terroristic violence that continues to plague the people and homelands of Jewish and Hindu traditions. In addition to these examples, evidence that the two groups are being specifically targeted from the same threat came on November 26, 2008. It was on this date, in the Indian city of Mumbai, where ten Islamic extremists shot and killed over 160 persons in the city's financial district, most notably at the Taj Mahal Palace and Tower (Bajaj, 2010). Among the victims targeted were some that came from a nearby Jewish center known as the 
Chabad-Lubavitch Nariman House where it was reported that, "Israeli hostages killed by Islamic terrorists during the attacks on Mumbai (formerly Bombay) were tortured by their captors before they were bound together and killed, according to officials in both countries" (McElroy, 2008). As my informants told me, and as can clearly be gathered from nature of the incident, Jews and Hindus were jointly targeted and affected not just by terrorism in general, but by the exact same act of terrorism!

The examples above clearly demonstrate why terrorism is perceived to be such a pressing threat for both factions. One reason for the existence of terrorism, and those who buy into it, deals with a lack of proper education and guidance which is covered in a veil of fundamentalist and extremist lies, according to Sri Swami Dayananda Saraswati, founder and convener of the Hindu Dharma Acharya Sabha. He made it clear that, “Terrorists don't know who the enemy is and they fear that they are in danger of losing their culture to modern society. The leaders are confused and use religion as a weapon. They believe this a direct ticket to paradise" (personal communication, 5/30/2010). These terrorists fear secularism as well, but believe the only way to combat it is through senseless violence and killing of the innocent.

Ashkenazic Chief Rabbi of Israel Yona Metzger made a similar remark at the first summit with reference to the creation of the State of Israel when he said:

Our neighbors did not agree, and during all the 60 years we suffered, as their religious leaders commanded them to kill themselves and to kill others, all for promises of pleasures in heaven. The poor families get money for every suicide bomber that they can sacrifice. (Metzger, 2007, p. 21)

The swamis believe that Muslim leaders misrepresent Islam when they teach their followers that their culture is in a state of peril. "Nobody is a terrorist by birth. They are 
created." Swami Parmatmanada informs me, "Religious leadership needs to take action" (personal communication, 5/18/2010). Again, it is with the religious leadership that responsibility for the propagation of terrorism is placed, and that makes dialogue with these leaders imperative if the current trend of terroristic violence is to be effectively stopped.

The notion of terrorism also poses a threat to Jewish and Hindu cultures through its obvious disregard of each group's most important ethical value: the upholding of the sanctity of life. This disregard can also be credited to a lack of knowledge or education, according to Swami Vishveshvaranada, who noted that, "Terrorism is a very big problem that comes from lack of knowledge of the value of human life on the Muslim extremist's part" (personal communication, 6/18/2010). As Rabbi Metzger said, "We value the sanctity of life. Even if someone put up his hand to hit his friend in anger, but does not hit his friend, he is considered wicked. For us, violence is one of the biggest sins in the tradition" (Metzger, 2007). The parallel to this concept in the Hindu faith is the premise of "ahimsa" or non-violence. Swami Parmatmananda highlighted the concept of "ahimsa" and where its source originates when he exclaimed, "According to Hindus, because all is God, all life must be respected and nobody, therefore, should be killed in the name of religion" (personal communication, 5/18/2010).

There is, however, an extremely important aspect that must be kept in mind with regards to the approach of both delegations towards the terroristic threat. This is not a rally against the Islamic faith. During my interview with Rabbi Rosen, he explicitly noted that, "This [dialogue] must not be seen as anti-Muslim" (personal communication, 6/24/2010). The fear of radical Islam is a consistent, ever-present danger affecting the 
Hindu and Jewish traditions, which therefore requires the leaders of these two faiths to take a very proactive stance towards the issue. Some Islamic leaders in India took it upon themselves to approach Swami Dayananda about accepting all religions, in particular the Israelis (Dayananda Saraswati, persona communication, 5/31/2010). In historic fashion, during a previously unscheduled third day at the Delhi summit, Moulana Jameel Ahmed Ilaysi, president of the All India Organisation of Imams of Mosques, signed a letter of peace [appendix F] and cooperation with Swami Dayananda Saraswati and Chief Rabbi Yona Metzger. The declaration which, among other precepts, condemned killing, rejected extremism, and forbade suicide, was an unexpected event described as being "loved" by the Jewish delegation while being seen as a bridge to the rest of the Muslim world (Rosen, personal communication, 5/31/2010). This also led to the unprecedented visitation of several of these Muslim leaders to Israel for a first hand look at Israeli society and the effects of Palestinian rocket attacks and the Palestinian-Israeli conflict. The event was the first of its kind and will hopefully not be the last. The great success of this visit to Israel can be understood from the words of Moulana Jameel Ahmed Ilaysi:

The Jews I have met here say that we are all children of Abraham, part of the same family. This is something I didn't hear in India. The Muslims in India should come and see things for themselves. My initial impression was that the Israelis are certainly dominating Muslims out here. Once I came here, that impression completely changed. I saw the reality on the ground, the mutual respect Israeli Arabs and Israeli Jews have for each other. Constant conflict is not the reality here. I saw that Muslims, Christians and Jews lived side by side happily, not at each other's throats. (Ratzlav-Katz, 2007)

It can be seen then what role the terroristic threat plays in a dialogue between the Jewish and Hindu delegations, and the great attention that must be present in dealing with this threat. Although terrorism is not unique to these two cultures alone, the nature of 
their specific problem with the terroristic threat certainly is. This nature is fostered in great part by the histories the two traditions have with the terrorist groups who commonly carry out attacks on them and the great strife that riddles the history that Judaism and Hinduism have with Islam I general. Additionally, modern-day conflicts that both Israel and India have with neighboring Islamic countries also work to enhance the severity of this nature. It is by taking this very nature into account that we find an aspect of life shared by the Hindu and Jewish traditions that is different when compared to other traditions. The fact that both traditions share his unfortunate link led them to place an important emphasis on it at the summit meetings. One significant result of this emphasized link can be seen in the treaty that was signed with the Muslim delegation. Another significant development for the Jewish faith came with the subsequent visit of this Muslim delegation to Israel which is a new stepping stone that could take the Jewish people of Israel one step closer to peace with their Islamic neighbors.

\section{Proselytization: The Destructive Nature of Conversion}

I was sitting in the office of Swami Dayananda Saraswati, located at his ashram in the tropical forests of southwest Tamil Nadu, at around one o'clock in the afternoon. I was waiting to begin another interview, but this time it was a bit different. This time I would have company, an audience in the room, who would make note of all that was being discussed. This audience was composed of a woman from Israel and a three person film crew who was at the ashram filming a documentary for Swami-ji. I had spent nearly two weeks at this particular ashram and as word spread about my reasons for being there, 
the documentary team took immediate interest. The concept of a Hindu-Jewish dialogue, and Swami-ji's role in it, was a process that they were largely unaware of. As the interview began I felt a bit nervous. I had never had an audience during my interviews before, but I listened attentively while Swami Dayananda explained the Hindu-Jewish encounter. He went on to describe the nature of religious tolerance in India and how Christians and Muslims proselytize by saying, "In India, every religion is allowed to practice religion. We don't have an issue" (personal communication, 5/31/2010). He continued:

It's very difficult to make the other people also live like that [without an issue]; it's very difficult because they can't live quietly. They have to convert. They rub all the time, that's how they survive. They have to rub. That is their commitment. So to change them is so difficult, so we try, we keep the dialogue going. (personal communication, 5/31/2010)

About half way through the interview, he asserted that, "If they [the proselytizers] believe that other religions should be destroyed, that belief is not acceptable. It's not human. Conversion is violence" (personal communication, 5/31/2010).

Proselytization, or forced conversion, is by definition an expression of disrespect according to Rabbi Rosen (2007c, p. 41). The sentiment among members of both delegations was that we have seen the creation of a formidable foe which has wreaked havoc on the Jewish way of life for centuries and may pose the single greatest threat to the Hindu culture during this modern day and age. As Rabbi Rosen pointed out, "Many Muslims and Christians in India see attempts at conversion simply as an "exchange of ideas' in a democratic society" (personal communication, 6/24/2010). From this perspective, the whole proselytization issue becomes even more dangerous in that the proselytizers truly have no realization that what they are doing is violent in nature. 
Acknowledging this circumstance, a considerable amount of time and energy was placed on discussing this topic at the summits, which is why I treated this as a separate theme from the previous two despite the fact that this is also a perceived cultural threat.

As I had briefly mentioned earlier, a view of non-proselytization is strictly adhered to by the two delegations involved in this dialogue. The tolerance for other religions exhibited by the two traditions involved in this dialogue is a key factor in their stance on non-proselytization.

A prime example of an inclination to proselytize in India can be seen during Pope John Paul the II's visit there in 2000. Swami Dayananda described this visit to me when he quoted the Pope in saying, "The cross was planted in the first millennium in Europe, it was planted in the $2^{\text {nd }}$ millennium in North America, South America, and Africa and will be planted in Asia in the $3^{\text {rd }}$ millennium" (personal communication, 5/31/2010). Rabbi Rosen added to this point when he noted that without John Paul's visit to India in 2000, inter-faith dialogue between the Jews and Hindu's never would have taken place (personal communication, June 24th 2010). On the basis of the positions they take towards other religious traditions, the use of a dialogue as an arena to gain potential converts has no place in this encounter between these Hindu and Jewish delegations. Professor Leonard Swidler, Christian dialogian at Temple University, notes the importance of this observed fact found in the Hindu-Jewish summits in his 'Decalogue of Dialogue' where his first commandment reads:

The primary purpose of dialogue is to learn, that is, to change and grow in the perception and understanding of reality and then to act accordingly. We come to dialogue so that we ourselves may learn, change, and grow, not so that we may force change on the other, our partner, as the old polemic debate hoped to do. (Swidler, 1990, p. 43) 
As Rabbi Rosen's words insinuate, this declaration by the Pope caused a great feeling of concern among these leaders of the Hindu tradition. The need to dialogue about nonproselytization became a top priority as the perceived reality of this cultural threat continued to grow.

Support against proselytization was voiced by all interviewees that I spoke to, as well as all who spoke at the summits. Not only do these particular Jewish and Hindu groups promote tolerance and respect for all world religions, but many of the leaders spoke of the necessity of the existence of these traditions. During the interview process, I had the honor of spending nearly an entire week with Swami Parmatmananda at his ashram on the outskirts of Rajkot, Gujarat. Besides a handful of students, and a few ashram workers, I was the only individual present at the establishment. The ashram itself was a lush oasis of vegetation and attractive buildings in the middle of a dry, dusty scrubland where the heat was always stifling during the daytime hours. I was privileged enough each day to sit with Swami Parmatmananda, speaking and discussing with him in a one-on-one fashion. It was here, during one of our discussions, that he presented me with an analogy regarding other faith traditions and the necessity of having them in the world. He said, "Exclusivity is the problem. Let the world have variety. Religion on this planet is like an orchestra and the multitude of instruments that must be a part of it. Some religions are less, some more, but all are equally important" (personal communication, 5/18/2010). Similarly, when I approached Swami Vishveshvaranda with his thoughts on this issue, he stated that, "Every religion's followers should study their own religion and find out the truths" (personal communication, 6/18/2010). This point is further amplified by a quote of Rabbi Sperber mentioned earlier: 
The same sunset can be seen by two people and each will give an accurate impression, which although different, will be truthful. Similarly, there are multiple truths of that which is outside of us. God creates everything that is not identical. We see truths in our own subjective fashion. There is no single, holistic truth; each person has his own truth (Sperber, 2007b).

These comments go beyond the fairly simple concept of respect and tolerance for other religions. They demonstrate the unquestionably legitimate value with which the leaders involved in this dialogue view other faith traditions. These other faith traditions are seen as entities that have something positive to share with and spread to others in the world. This type of sincerity towards the value of other faith traditions is not common place. The sincerity of value placed on the other's tradition depicts another aspect of dialogue that has been, up until this point in history, quite rare and seldomly verifiable in other inter-religious encounters.

If attention is turned to how proselytization has affected the two respective traditions involved throughout their histories up until the present-day, yet another reason can be established as to why the discussion of this theme was so important to the dialogue. The current threat in our modern day and age of forced conversion is more crucial for Hindus in India than for Jews of Israel or elsewhere. The threat being more crucial for Hindus than for Jews is because of the fact that, after centuries of fighting this threat, Jews have developed viable strategies and made significant progress in combating proselytization. The Hindu participants wanted to learn strategies to help India's Hindus to better deal with their own struggles against forces of exploitive conversion attempts. As Sri Venkatanarayanan, General Secretary of the HDAS pointed out to me, "Hindus only recently, in the last 150 years, began to approach, recognize, and combat conversion attempts from 'outsiders'" (personal communication, 5/27/2010). 
The cultural survival of the Jews throughout their history can be attributed partially to their ghettoization by Gentile rulers that isolated the Jews from the rest of society, in addition to their sheer will to survive. Fortunately, contemporary circumstances have improved dramatically for Jews in many places around the globe and another giant step towards this improvement came over the last decade as Sperber noted when he said that, "We [the Jews] have never been a proselytizing nation and we have always been against being proselytized. We came to an agreement with the Vatican with the last Pope [John Paul the $2^{\text {nd }}$ ] that he would forbid any kind of proselytization in Israel" (personal communication, $7 / 11 / 2010$ ). This was a key victory for the Jews of Israel in their centuries old fight against conversion attempts, and the agreement between the Vatican and the Chief Rabbinate is a model the HDAS hopes to replicate, according to Swami Dayananda. The swami hopes to engage in a similar discussion with the Vatican, with the goal of ending Catholic proselytization of Hindus (personal communication, 5/31/2010). Swami Dayananda went on to explain that, according to the views of many other religious traditions, Hindus do not pose the threat of religious dominance and are looked down upon as possible victims, as ones to be helped in terms of having a backward religious tradition (personal communication, 5/31/2010). "They think they have to help the Hindus," says Swami Dayananda, "that they [Hindus] are outside the flock. They need to be brought back inside the flock" (personal communication, 5/31/2010). This perceived negative view of Hinduism by many of the world's major faith traditions is also recognized by Jewish leaders as well. Professor Dov Maimon, senior fellow at Hebrew University’s Jewish People Policy Institute, described the problem the Hindus face in this respect by noting that, "The threat is 
missionary Christians. Also, maybe Islam. These two groups of people come to them and tell that "you are a primitive religion, you are a popular religion, you have no base and so on" (personal communication, 7/11/2010). This described negative view towards Hinduism deters leaders of other religious groups from dialoguing with them, it is believed. Swami Parmatmananda put it best when he described this dilemma in saying, "Those who are strong do not feel the need to sit with the weak" (personal communication, 5/18/2010).

As has been the case with many of the issues facing both delegations, education is again a key factor in neutralizing what they see as the conversion threat. According to members of the Hindu delegation, the problem in India is a lack of an adequate educational system that teaches about Hindu tradition and represents it in a positive fashion. A solid education which positively promotes the true nature of the Hindu culture is a means to strengthening their group identity, according to Rabbi Rosen (personal communication, 6/24/2010). Elite education in India is often found in the private sector that, unfortunately for Hindus, is dominated by Christian-based schools (Rosen, personal communication, 6/24/2010). As a result of their inherent lack of education that serves to preserve tradition, Swami Dayanada asserts that Hindus in India do not even realize they are under attack and are frequently tricked into conversion by missionaries (personal communication, $5 / 31 / 2010$ ). The Jewish role in aiding the Hindus comes with their strength in education. On the whole, Jews are perceived by many to be a well educated group of people. Their highly educated nature is demonstrated on an international scale with Jewish over representation in fields such as politics, business, and science to name a few. In this fashion, the Hindus said they would like to learn from the Jews about how to 
preserve their tradition to combat threats and to educate their people about converts (Dayananda Saraswati, personal communication, 5/31/2010).

This is a significant development for the Hindu delegation as far as what they have gained in their struggle against the perceived threat of conversion. The progression of this dialogue gives them a new allied support in their fight against proselytization and a framework from which they can learn to combat this threat.

\section{Self-Defining Identity: History, Symbols, and Monotheism}

I was overwhelmed by the smell of spices in the air, a dozen shopkeepers inviting me into their shops, and the sight of 2,000 years of Indian Jewish history in front of my eyes. I had just emerged from Paradesi Synagogue in the 'Jew Town' section of Cochin, Kerala. The day was warm, humid, and misty. It was the beginning of the rainy season during my visit to the Malabar Coast and the scarcity of visitors reflected this time of year. Peering along the roads, I took in the extraordinary amalgamation of religion, language, and people. Hindus, Muslims, Christians, Jains, and of course, Jews, were working, sharing, and living side by side. This multi-faith atmosphere defines every day life here and immediately instilled in me an understanding of how and why Jews were so well received on these shores nearly two-thousand years prior to my visit. As I continued my journey through ancient streets and narrow paths of Old Cochin, I find my self wandering down a quiet corridor towards a Hindu temple. I entered to find it empty and serene, absent of any worshipers. Looking around, I took notice of statues of several Hindu gods and goddesses. There was Rama, incarnation of Vishnu and hero of the epic 
Ramayana and there was the monkey god Hanuman, symbol of strength and recognized for his undying devotion to Lord Rama. At the center of the temple, in an area that was locked in its own sanctum, was a lingam altar to Shiva, the god of destruction and the ultimate yogi. Walking out of the sacred building, I took notice of the beautifully intricate iconography that adorned a neighboring temple which included what many non-Hindus would consider a volatile symbol, a swastika. My background allowed me to immediately understand all that I had viewed at these temples, but what would other outsiders think? That the use of the swastika is a mistake? That primitive, idol worshiping pagans are the norm in this society? Or perhaps maybe that Nazism has taken hold here?

The potential reactions mentioned above are the unfortunate outcome of centuries of demeaning misrepresentations of the Hindu religion that have now become a reality for the devout Hindu. As Leonard Swidler's fifth rule of dialogue explains, "Each participant must define her- or himself" $(1990$, p. 44). The concept of self-definition is absolutely essential with regards to the manner in which the histories, sacred symbols, and beliefs of Hindus, as well as Jews, have been perceived by outsiders. The lack of acceptance of the self-definition of these groups has had, and continues to have, ill effects upon the followers of these timeless traditions. The tumultuous history of the Jewish people has been well attested throughout the pages of history with examples of physical violence directed towards them. The violence and influence of Hellenistic culture threatened to erase the identity and even the existence of the Jewish people at various times. The threat of violence continued to be ever present into the first millennium of the Common Era and into the second, especially with regards to the relentless persecution 
that took place in medieval Christian Europe. This violent and hateful treatment of the Jewish people all culminated in what is considered to be the most atrocious and diabolical undertaking in human history, the Holocaust. Much of this suffering that Jews have endured in the last two thousand years stems from the misunderstanding and misrepresentation of the Jewish religion by outsiders.

Although not as widely realized as that of the Jews, the history of the Hindus shows that they have suffered through their fair share of violence and oppression, especially under particular periods of Mughal and British rule. Harsh treatment for Hindus persisted under the Mughal ruler Aurangzeb. As a result of a series of edicts he made throughout the 1660's, Hindu shrines were destroyed, the building of temples was restricted and new taxes were imposed on Hindu merchant and pilgrims, who were then forced to pay twice the rate of Muslims (Stein, 1998, p. 179). Conditions under British control were just as appalling and, at times, seemingly worse. Slavery, said to have affected over eight million Indians, continued to be widespread even after its abolishment in 1843 (Stein, 1998, p. 217-219). Just as in North America, during British control "As colonial subject, Indians were neither invited nor permitted to enjoy the right of 'freeborn Englishmen,'" (Stein 1998, p. 227). Much of the violence towards the Hindu tradition during the modern time period, however, comes in the form of a misrepresentation of their beliefs and sacred symbols and a neglect of their dignity and cultural accomplishment.

The defining of history by outsiders is an issue that has much relevance for Hindu and Jewish participants. At the first summit meeting between the two delegations, discussions about the self-definition of Hindu history centered on the story of the Aryan 
invasion of India. Professor Rajiv Malhotra of the Infinity Foundation noted that it is an issue that is very much alive today, and is seen as having caused great harm to both Jews and Hindus (Malhotra, 2007, p. 40). It was crucial in the summit dialogues for the Jews to understand the truth of the origins of Hindu culture. This impetus was because of the consequences of the traditional false representation of Hindu history and its symbols among the Jewish people, most notably the swastika. With regards to this false representation and its consequences, Professor Malhotra of the Hindu delegation noted:

In the $19^{\text {th }}$ century, the Aryan theory was formulated by scholars, which said that Sanskrit and Vedas came to India from the West, where it got diluted to become Hinduism, and to take credit for the wonder of the Sanskrit language. The theory that posited Nazi superiority was based on the same fabricated Aryan identity, and led to the Holocaust. This theory has been creating havoc in India. It says that what we practice in not Hinduism, but an upper caste fabrication. (Malhotra, 2007, p. 40)

The $19^{\text {th }}$ century Aryan theory has raised feelings of concern among both traditions. According to Malhotra, the "Aryan invasion theory" strips the Hindu people of the credit they deserve as being the source and engineers of all the wonders that comprise the ancient Hindu tradition. At the same time, the Aryan theory also charges Hindus with negatively altering a great tradition into a corrupt version of what it formerly was. This is an ignorant and harmful gesture towards the Hindu tradition which brings into question their achievements, values and, essentially, their entire identity. The result of an acceptance of this theory is a lack of respect for Hindu people and tradition. This negative perception of Hinduism has devastating effects within the culture as well, causing Hindus to be ashamed of their heritage and turn away from their roots in favor of what are perceived to be "more respectable" ways of life. 
The affect this theory has had on the Jewish people is a deep, dark legacy which caused them to suffer at a level never before seen. The purported supremacy of the Aryan race was a foundation for Nazi ideology in their attempt to exterminate European Jewry during the Holocaust. The adaptation of this theory by Nazis, led them to use one of Hinduism's most revered and auspicious symbols as the ultimate representation of all they believed, propagated and fought for, the swastika.

The swastika symbol and its meaning was distorted and misused by the Nazis during the Holocaust and, in part, as a representation of their belief and commitment to Aryan supremacy resulting from the existence of the "Aryan Invasion Theory". With regards to the swastika, Malhotra mentions that:

The Nazis used the swastika as a symbol. Not only Hindus, but Buddhists and Jains also used the swastika. The appropriation of the swastika went hand in hand with the theory. It became a symbol of Aryan superiority. This is one of the challenges that both our communities should have to overcome. $(2007$, p. 40)

Additionally, during the contemporary time period, the swastika has become the international symbol for neo-Nazi and white supremacy groups the world over. It not only continues to be perceived in this fashion by many outside of India, but it is still being used by groups as an active symbol of hate and bigotry, everything the Hindu tradition stands against. In this manner, the swastika continues to have a negative effect on Hindu and Jewish traditions that each desires to shed and transform. The process of understanding the true nature of this symbol was begun at these meetings when several pleas were made by the Hindu delegation for the Jews to accept the nature and the use of the symbol. At the first summit, Swami Dayanada Saraswati remarked, "While I totally condemn the use of the Swastika 
in any other context, I appeal to the Jewish leadership to appreciate our Hindu sentiment and totally accept this symbol for use as an auspicious symbol" (2007b,

p. 39). In a similar appeal, at the second summit, Swami Parmatmananda stated:

I request our Jewish friends to appreciate this fact that the swastika also has been, for generations, a symbol of the Lord. For not only centuries, but for thousands and thousands of years swastika is a sacred symbol for us and in every house and every village if you go, you will find this. Even on marriage invitations it will be printed. I request our Jewish friends to appreciate our position. (2008b, p. 38)

Considering all that this symbol has meant and denoted for the Jewish people over the last seventy years, it takes a serious commitment to understanding to meet a request such as this, which the Jewish delegation conceded to do. As Rabbi Rosen stated:

The way to address this technically at least, is through the area of holocaust education so hat people have a better understanding of how Hindu culture was distorted, abused, and continues to be denigrated by a group of vested interests. (2007c, p. 41)

Rosen suggests that the key here is, again, education. It is not only a lack of education, but a lack of proper education. The original meaning of this symbol needs to be taught in conjunction with the horrific meaning it has come to be associated with by most.

The existence of, and consequences from the "Aryan Invasion Theory" create another unique point of dialogue between the two particular traditions. It is a distinct, albeit unfortunate, similarity which aided in making this encounter a reality. The swastika was one of the significant issues that informed the shape and meaning that this dialogue took on as well as the resulting relationship the two groups have had since the encounter. The reinterpretation and understanding of the swastika symbol is an 
exceptional breakthrough which aids in restoring truth and dignity to the Hindu tradition, while highlighting the deep level of sincerity at which these meetings were held. It is a level of sincerity and area of very sensitive understanding which must not be over looked when considering the ways in which these meetings demonstrated new and significant developments for both traditions.

Nowhere, perhaps, was the notion of self-definition of tradition more important, or the understanding more impressive, in this encounter than it was with regards to the intellection of Hindu monotheism. From the viewpoint of the both delegations, the acknowledgement of Hinduism as a monotheistic tradition by the Jews was an absolute must, but for differing reasons. Therefore, a great deal of time was spent thoroughly exploring this theme. For the Hindus, the recognition by the Jews of them as believing in only one God is the key to gaining the respect of other religious communities around the globe, particularly within Christian and Islamic factions. These two factions have their roots in the Jewish religion and it is widely recognized that the Jews were among the first to embrace the concept of the monotheistic worship. In this fashion, their Jewish rulings and opinions on the singular nature of the divine are therefore highly regarded. With reference to this fact, Dr. Maimon quoted Hindu leaders in saying, "We want you to give us legitimation that we are monotheists" (personal communication, 7/11/2010). This recognition will, in turn, open doors of dialogue with leaders of other religious communities in hopes of breaking the barriers of misunderstanding that most have about the Hindu tradition.

The Jewish reason for verification and acceptance of Hindus as monotheists relates to precepts of Halacha. As Rabbi Sperber explained, "From our point of view the 
issue [monotheism vs. polytheism] is important because according to Jewish law, we are not really meant to have any kind of a close relationship with idolaters" (personal communication, 7/11/2010). From the halachic perspective, the mere meeting with the Hindu delegation was highly contingent upon the sincere acceptance of Hinduism as a monotheistic religion. This makes the affirmation of the Hindu religion as a monotheistic tradition absolutely basic in order for the Orthodox Jew to have any kind of relationship with them in many cases.

The reasons of the Jewish delegation for recognizing this ruling on the monotheistic nature of Hinduism of this particular group of Hindus is again tied to Halacha. Rabbi Sperber's words represented the entire Jewish delegation when he stated, "And I've seen halachic discussions where in it is clearly stated the rabbinic position on Hinduism should be determined in accordance with the authoritative understanding of the religion as opposed to the popular understand of the religion" (personal communication, 7/11/2010). He continued with reference to the Hindu authorities present by saying, "We had a fairly representative body of people coming from many different parts of India. That's what was important and they all came to much the same conclusion which was important to understand" (personal communication, 7/11/2010). This representative body of Hindu leaders was the key to the Jewish delegation making a complete reversal of their previous belief that Hinduism was a polytheistic religion and it created a circumstance that allowed the dialogue to proceed in such a productive manner (Sperber, personal communication, 7/11/2010).

Hindu leaders were very assertive in speaking about monotheism. Monotheism is the only topic that nearly every individual I spoke with, or who spoke in the summit 
reports, was sure to comment on and verify at some point during the discussion. During Swami Dayananda's opening remarks at the initial meeting, he states that the very first precept of the Hindu religion is, "There are not many Gods. There is only one God" (Saraswati, 2007a, p. 14). From the outset of this dialogue, the eagerness with which the Hindu delegation had in communicating their monotheistic belief can be observed. Sri Swami Viditatmananda expands on the concept on monotheistic belief in Hinduism by saying that:

All that there is God. Whatever has form also has manifestation of God. God can be worshipped as something beyond forms, but at the same time, whatever has form, also has the presence of God. We find Hindus worshiping God in forms. It is not that the person worships the idol, metal or stone, that is in front of him, but it becomes a stepping stone for worshiping God. (2007, p. 36)

One reason for the existence of this method of worship deals with devotees' varying levels of understanding of the divine. Some need props, names, and forms to get in touch with the divine where as the more sophisticated ones may not require these aids in worship (Viditatmananda, 2007, p. 36). As Swami Parmatmananda said to me, "Every emotion requires a form to express it" (personal communication, 5/31/2010). This necessity for a "vehicle" of worship for some practitioners has consensus among the Hindu leaders who all affirmed their adherence to a monotheistic belief in the divine. This practice of using forms in worship is justified in their understanding that all is God. Swami Parmatmananda reinforces this belief in saying, "We do not say that there is one God, please understand, we go one step further Hindu tradition says that there is only God" (2008a, p. 29). 
The Hindus' understanding of themselves as a monotheistic faith was a carefully formulated premise that came as "great surprise" to the Jewish delegation, as Rabbi Sperber described (personal communication, 7/11/2010). Similarly, Rabbi Shear Yashuv Cohen, Chief Rabbi of Haifa, said, "I must say that I was surprised to learn that behind the many names of Gods that you find in India, there was one supreme God" (Cohen, 2008, p. 33). It was a premise that, nevertheless, was accepted by the Jews. It is clear though, that the previous view by the members of this delegation was of all Hindus as polytheists. Rabbi Rosen further described the newly refined Jewish delegation's understanding of the Hindu concept of the divine denoting that it shared the essence of monotheism and by using the Hebrew word shituf, which refers to the association of different dimensions with deity (personal communication, 7/11/2010). From Rosen's insight, one can see how the Hindu view of God can be conceptualized and made permissible within a halachic framework. By equating the various Hindu incarnations of God (i.e. Vishnu, Shiva, etc.) with differing dimensions of a single God, rather than equating them with individual and separate gods, the Hindu religion can now be realized as a monotheistic tradition in terms of Jewish law.

By looking at the aspect of this dialogue dealing with self-identity, we find a number of developments that are both rare and remarkable. The first important development was the Jewish recognition of the original meaning of the swastika symbol, which took a deep level of understanding and sincerity. This level of understanding is not only observed in the printed report of each meeting, but is something that was also verified by every Hindu and Jewish leader which I interviewed. The leaders of both delegations were seemingly absent of any type of superficial understanding of the other's 
tradition, which was also quite relevant in the discussion on monotheism; a claim verified by Swami Parmatmananda and Rabbi David Rosen during the interview process (personal communication, 5/31/2010\& 7/11/2010).

The second development deals with the remarkable reversal of a deeply ingrained, two thousand year old belief of Hindus being polytheistic idol worshipers on the part of the Jews. This instance of belief on the part of the Jews goes contrary to Swidler's sixth commandment of dialogue which states that, "Each participant must come to the dialogue with no hard-and-fast assumptions as to where the points of disagreement lie" (1990,p. 44). After the meeting, both delegations sincerely understood the reformed Jewish position on the Hindu concept of the divine. Swami Parmatmananda confirmed the Hindu belief in the Jewish reversal of thought by saying, "Rabbi Sperber said that a 2,000 year old confusion had been reconciled" (personal communication, 5/31/2010). The retraction of a two thousand year old belief during the first ever dialogue between these two groups is a seemingly unparalleled fact that further illustrates the significance this dialogue has for both traditions. As Rabbi Sperber said, "One of the great achievements of our first meeting in Delhi was when we signed together a declaration clarifying what is not understood by most people, that Hindus basically are a Monotheistic religion as is Judaism, Christianity, and Islam" (2008b, p. 32). This acceptance by the Jewish delegation of the Hindu delegation as being monotheistic is a perfect demonstration of Swidler's first commandment quoted earlier and how one must be open to the possibility of changing oneself as a result of dialogue. 


\section{Chapter 6: Concluding Thoughts \& Arguments}

The description and analysis of this historic encounter clearly attests to the new level of sincere understanding on some very delicate issues with the most notable example being found in the reversal of the deeply rooted 2000 year old Judaic belief about Hindu polytheism. The acceptance of Hinduism by the Jews as a monotheistic tradition is one of several affirmations listed on the pair of declarations which was signed by all members of each delegation at the meetings in Delhi and Jerusalem [appendices G, $\mathrm{H}$, and I]. The affirmations in the declarations that were signed by the members of both delegations closely mirror the concerns and themes which were discussed and evaluated at each meeting. It is my assessment that each affirmation listed in the declarations was talked about at equal length during the summit meetings. I did not feel that this was the case with regard to the interviews, however. During the interview process, two themes stood out as receiving more attention than the others: the notion of Hinduism as a monotheistic faith and the effort to combat proselytization. The focus on these themes came as no surprise for two reasons. The first is that the recognition of Hinduism as a monotheistic faith by the Jewish delegation was the most notable breakthrough of this dialogue. That can be gathered from the explicit acknowledgement of this fact by Jewish leaders in the summit reports and by looking at what the Jewish perception of Hinduism had been up until the occurrence of these meetings. The second deals with the fact that proselytization of Hindus in India is currently the most pressing concern for the Hindu delegation, and therefore, requires a great deal of attention if they hope to resolve this perceived issue. 
Another pair of outcomes which were the result of the first meeting at Delhi were a standing committee on Hindu-Jewish relations and a Hindu-Jewish scholars group.

These are significant developments for both traditions in which they both will benefit from mutually. Their purpose, as described by the ninth affirmation of the second declaration signed in Jerusalem, reads:

The bilateral groups of scholars may engage in further elaboration of the foregoing affirmations, exchange material to enhance mutual understanding, clarify positions of the Hindu and Jewish traditions regarding temporary challenges in science and society, and identify programs of action for the future. ("Declaration of the", 2008, p. 9)

These groups are designed to continue the progression of these meetings forward after their culmination and to foster the developments that have resulted from this dialogue. Presently, however, the practical use of this development of the formulation of these groups, has yet to materialize in either Indian or Israeli society.

There is also significance in the straight forward undertone present throughout the duration of the dialogue process. As Rabbi Brodman, Chief Rabbi of Savyon notes:

I would like to thank the Almighty, for the occasion that we are here to speak and listen to you [the Hindus], because we, the rabbinical council, had meetings in Rome and in Jerusalem with the Cardinals. We made a point of it not to talk about theology, we only spoke about things that we have in common. Yet I thank the Almighty, today we diverted a bit from that principle (2008, p. 37).

According to this statement, the forthright approach in highlighting differences and misconceptions between the two traditions is evidence of a way to engage the other which these groups perceive diverges from the major pattern found in many other interfaith dialogues. There seems to be an apparent difference in the manner in which these two religious traditions relate to one another in comparison to how they relate to other traditions in other dialogues. This special relation to one another is a significant 
development that each group can analyze and learn from for the benefit of future dialogues with other groups. This was voiced by leaders and supported by the observable progress of communication and events which took place at these meetings.

The practicality of the dialogue, resulting from the new position of the Chief Rabbinate on the issue of Hindu monotheism, is another important aspect that can be exemplified with reference to Jews in the trade market. Being that Jews are not to have close relations with those classified as "idolaters," it would be Halachically impermissible to trade with Hindus if they were ruled to be polytheists. Rabbi Sperber summed this notion up by saying:

We are not meant to benefit from them [idolaters] and their products and we are thinking in terms of international trade. I mean the government doesn't function along traditional Jewish law, but if you are to ask an Orthodox rabbi, judge, whether it is permitted to have a trade agreement with an Indian producer, manufacturer for them there would be a number of problems involved (personal communication, 7/11/2010).

As a result of this dialogue, however, this everyday occurrence (i.e. Hindu-Jewish trade) can now be justified according to Halacha.

The role that subject matter plays in the occurrence of significant developments in this dialogue is also instrumental. As can be deduced from the nature of the themes analyzed, many of the topics which were discussed create a bridge that is presented as being particular to a meeting between these two groups. These themes are another very interesting aspect of this dialogue that creates a unique way of relating to one another and an incentive for meaningful relations. A lack of mutually relatable themes between the delegations would have weakened the bond that produced the level of progress present in the dialogues and it would have therefore deemed the encounter less important and perhaps less relevant. 
Other new and significant developments were detailed with their respective themes and include the occurrence of a meeting of "non-universal" religions, the unexpected agreement with the All India Organisation of Imams of Mosques, and the recognition by the Jewish delegation of sacred Hindu symbols as defined by the Hindu delegation.

It is in considering all of these points that I have found evidence that new and significant developments for Hinduism, Judaism, and the Hindu-Jewish dialogue resulted from this encounter. The developments that have resulted from this dialogue do appear to vary with regards to their significance and some may take several years before we are able to observe their full potential and the impact they will have. In any case, I feel that the progress, the high level of understanding, and the practicality generated by this dialogue confirms the existence of new and significant developments for Hinduism, Judaism, and the dialogue that continues on between them. 


\section{BIBILIOGRAPHY}

(n.d.). The Hindu dharma acharya sabha: the collective voice of hindu consciousness. Retrieved from http://www.acharyasabha.org/ index.php?option=comfrontpage \&Itemid $=1$

$\mathrm{n} / \mathrm{a}$ (2007). A broad outline of the dialogue. Proceedings of the first hindu-jewish leadership summit (pp.4) New York, NY: World Council of Religious Leaders

$\mathrm{n} / \mathrm{a}$ (2007). The declaration of mutual understanding Proceedings of the first hindu-jewish leadership summit (pp.46) New York, NY: World Council of Religious Leaders.

n/a (2007). Participants. Proceedings of the first hindu-jewish leadership summit (pp.6163) New York, NY:World Council of Religious Leaders.

$\mathrm{n} / \mathrm{a}$ (2008). Declaration of the second hindu-jewish leadership summit Proceedings of the second hindu- jewish leadership summit (pp. 8-9) New York, NY: World Council of Religious Leaders.

$\mathrm{n} / \mathrm{a}$ (2008). Participants. Proceedings of the second hindu-jewish leadership summit (pp.57-58) New York, NY: World Council of Religious Leaders.

(2007, March 30). Chennai convention resolution - november 2003. Retrieved from http://www.acharyasabha.org/index.php?option $=$ com_content\&task=view\&id $=28 \&$ Itemid $=41$

(2007, March 30). Mumbai convention resolution - october 2005 . Retrieved from http://www.acharyasabha.org/index.php?option=com_content\&task=view\&id $=16 \&$ Itemid $=41$

Gauḍiya vaiṣnava. (1992). In S.J. Rosen (Ed.), Vaiṣnavism: contemporary scholar discuss the gaudiva tradition (pp. 7-17). Delhi, India: Motilal Banarsidass Publishers.

Bajaj, V. (2010, May 3). Pakistani Man Convicted in 2008 Mumbai Attacks.

Hindustan Times. Retrieved from http://www.nytimes.com/2010/05/04/ world/asia/04mumbai.html

Benjamin, Abraham. (2007). The history of jews in western india. Proceedings of the The hindu-jewish leadership summit (pp. 38-39). New York, NY: N/A.

Brill, A. (2010). Judaism and other religions: models of understanding. New York, NY: Palgrave Macmillan. 
Brodman, D. (2008). Open dialogue. Proceedings of the $2^{\text {nd }}$ hindu-jewish leadership summit (pp. 31-38) New York, NY: World Council of Religious Leaders.

Cohen, A.S. (1984). Halacha and contemporary society. United States of America: KTAV Publishing House

Cohen, S.Y. (2008). Open dialogue. Proceedings of the $2^{\text {nd }}$ hindu-jewish leadership summit (pp. 31-38) New York, NY: World Council of Religious Leaders.

Dandekar, R.N. (1987). Vedas. Encyclopedia of religion. Detroit: Macmillen Reference USA

Fendel, H. (2008, September 11). Candidates line up for chief rabbinate council elections. Retrieved from http://www. israelnationalnews.com/News/ news.aspx/127577

Guitierrez, G. (1988). A theology of liberation: history, politics, and salvation. Maryknoll, NY: Orbis Books.

HT Correspondent. (2010, December 8). Terror Strikes Varanasi. Hindustan Times. Retrieved from http://www.hindustantimes.com/Terror-strikesVaranasi/Article1-635726.aspx\#

Historical information concerning our house. (n.d.). Retrieved from http://www.ausrianhospice.com/en/hospiz.htm

Hopkins, T.J. (1971). The hindu religious tradition. Belmont, California: Wadsworth Publishing Company.

Jain, B. (2007). Hindu-jewish leadership summit: an initiative of the world council of religious leaders Proceedings of the $1^{s t}$ hindu-jewish leadership summit (pp.3). New York: World Council of Religious Leaders.

Katz, N. (1997). How the hindu-jewish encounter reconfigures the interreligious dialogue. Shofar, 6(1), 7-22.

Katz, Nathan. (1999). India and israel in the ancient world. Shofar, 17(3), 7-22.

Katz, N. (2000). The identity of a mystic: the case of sarmad, a jewish-yogi-sufi coutier of the mughals. Numen, 47, 142-160

King, L.; Zer T. (2004, September 1). 16 Israelis Die in Dual Suicide Bus Bombings. Los Angeles Times. Retrieved from http://articles.latimes.com/2004/sep/01/ world/fg-busbombs1 
Knitter, P.F. (1995). One earth many religions: multifaith dialogue and global responsibility. Maryknoll, NY: Orbis Books.

Knitter, P.F. (1996). Jesus and the other names: christian mission and global responsibility. Maryknoll, NY: Orbis Books.

Knitter, P F. (2002). Introducing theologies of religion. Maryknoll, NY: Orbis Books.

Kreeft, P.J. (2001). Catholic christianity: a complete catechism of catholic beliefs based on the catechism of the catholic church. San Francisco: Ignatius Press.

Madhav Priyadas, S. (2008). Open dialogue. Proceedings of the $2^{\text {nd }}$ hindu-jewish leadership summit (pp. 31-38) New York, NY: World Council of Religious Leaders.

Malhotra, R. (2007). The Aryan myth and its consequences For the hindu religion. Proceedings of the $I^{\text {st }}$ hindu-jewish leadership summit (pp. 19-24). New York, NY: World Council of Religious Leaders.

McCarthy, K. (2007). Interfaith encounters in america. New Brunswick, NJ: Rutgers University Press.

McElroy, D. (2008, December 1). Mumbai Attacks: Jews tortured before being executed during hostage crisis. The Telegraph. Retrieved from http://www.telegraph.co.uk /news/worldnews/asia/india/3539171/Mumbai-attacks-Jews-tortured-beforeexecuted-during-hostage-crisis.html

Metzger, Y. (2007). Inaugural address. Proceedings of the $1^{\text {st }}$ hindu-jewish leadership summit (pp. 19-24). New York, NY: World Council of Religious Leaders.

Mookerji, R. (1962). Asoka. London: MacMillan

Panikkar, R. (1999). Inter-religious dialogue. New York, NY: Paulist Press.

Parmatmananda, S. (2008a). The hindu values. Proceedings of the $2^{\text {nd }}$ hindu-jewish leadership summit (pp. 27-30) New York, NY: World Council of Religious Leaders.

Parmatmananda, S. (2008b). Open dialogue. Proceedings of the $2^{\text {nd }}$ hindu-jewish leadership summit (pp. 31-38) New York, NY: World Council of Religious Leaders.

Parmatmananda, S. (2008c). Preservation of tradition in modern secular society. Proceedings of the $2^{\text {nd }}$ hindu-jewish leadership summit (pp. 45). New York, NY: World Council of Religious Leaders. 
Pratt, D. (2005). The challenge of islam: encounters in interfaith dialogue. Burlington, VT: Ashgate Publishing Company.

Promislow, Aryeh. (n.d.). Biography. Retrieved from http://www.rabbidavidrosen.net/ bio.htm

Puri, J (2006a, May). Renaissance of hindu dharma. Retrieved from http://www.vivekanandagospel.org/renaissance.htm

Puri, J (2006b, May). The renaissance of hindu dharma in the new millenium.

Retrieved from http://www.vivekanandagospel.org/renaissance ofhindudharma.pdf

Puri, J (2006c, May). A sabha whose time has come. Retrieved from http://www.vivekanandagospel.org/acharyasabha.htm

Rambachan, A. (1989). Swami vivekanada: a hindu model for interreligious dialogue. In M. Bryant, F. Flinn (Eds.), Interreligious dialogue- voices from a new frontier (pp. 9-20). New York, NY: Paragon house Publishers.

Ratzlav-Katz, N. (2007, August 21). Indian muslim leaders praise israel during visit. Retrieved from http://www.israelnational news.com/News/News.aspx/123448

Rosen, D. (2007a). Inaugural remarks Proceedings of the $1^{\text {st }}$ hindu-jewish leadership summit (pp.25). New York, NY: World Council of Religious Leaders.

Rosen, D. (2007b). Response: altars of worship in hinduism. Proceedings of the $1^{\text {st }}$ hindu-jewish leadership summit (pp. 36-37). New York, NY: The World Council of Religious Leaders.

Rosen, D. (2007c). The Aryan myth, and its consequences for the hindu tradition: response. Proceedings of the 1st hindu-jewish leadership summit (pp.40-42). New York, NY: World Council of Religious Leaders.

Rosen, D. (2008). Preservation of tradition in modern secular society. Proceedings of the $2^{\text {nd }}$ hindu-jewish leadership summit (pp. 39). New York, NY: World Council of Religious Leaders.

Saraswati, S.D. (2007a). Inaugural address Proceedings of the $I^{\text {st }}$ hindu-jewish leadership summit (pp.39). New York, NY: World Council of Religious Leaders

Saraswati, S.D. (2007b). The history of the jews in Western india: response. Proceedings of the $1^{\text {st }}$ hindu-jewish leadership summit (pp.39). New York, NY: World Council of Religious Leaders. 
Schwarzfuchs, Simon. A Concise History of the Rabbinate. Cambridge, MA: Blackwell Publishers, 1993. Print

Sharma, A. (1981). Svami dayananda sarasvati and vedic authority. Religion in Modern India, 179-196.

Singh, B.K. (2010, December 7). Terror strikes Varanasi:1 dead, 25 hurt in blast at ghat. The Times of India. Retrieved from http://timesofindia. indiatimes.com /city/varanas i /Terror-strikes-Varanasi-1-dead-25-hurt-in-blast-atghat/articleshow/7060311.cms

Singhvi, L.M. (2007). Inaugural Speech. Proceedings of the $1^{\text {st }}$ hindu-jewish leadership summit (pp.23-24). New York: World Council of Religious Leaders.

Smith, B K. (1998). Questioning authority: constructions and deconstructions of hinduism. International Journal of Hindu Studies, 2(3), 313-39.

Smith, B K. (2000). Who Does, can, and should speak for hinduism? Journal of the American Academy of Religion, 68(4), 741-749.

Sperber, D. (2007a). An overview of jewish tradition. Proceedings of the $1^{\text {st }}$ hindu-jewish leadership summit (pp. 29-30). New York, NY: The World Council of Religious Leaders.

Sperber, D. (2007b). The principle of mutual respect. Proceedings of the $1^{\text {st }}$ hindu-jewish leadership summit(pp. 35-36)New York, NY: World Council of Religious Leaders.

Sperber, D. (2008a). Transmitting values through our calenders. Proceedings of the $2^{\text {nd }}$ hindu-jewish leadership summit (pp. 22-26). New York, NY: World Council of Religious Leaders.

Sperber, D. (2008b). Open dialogue. Proceedings of the $2^{\text {nd }}$ hindu- jewish leadership summit (pp. 40-44). New York: World Counci of Religious Leaders.

Sperber, D. (2008c). Preservation of tradition in modern secular society. Proceedings of the $2^{\text {nd }}$ hindu-jewish leadership summit (pp. 40-44). New York: World Council of Religious Leaders.

Stein, B. (1998). A history of india. Oxford, UK: Blackwell Publishers.

Swidler, L. (1990). After the absolute: the dialogical future of religious reflection. Minneapolis, MN: Augsburg Fortress. 
Viditatmananda, S. (2007). Altars of worship in hinduism. Proceedings of the $2^{\text {nd }}$ hindujewish leadership summit (pp.36-37). NewYork: World Council of Religious Leaders.

Vishveshvarananda, S. (2007). The framework of the hindu dharma. Proceedings of the $I^{\text {st }}$ hindu-jewish leadership summit (pp.27-28). New York: World Council of Religious Leaders.

Viswanath, P.V. (2007). The hindu-jewish encounter, new delhi, february 2007. The Journal of Indo-Judaic Studies, 9, 108-113.

Weinstein, B. (2007). Trader and ideas: indians and jews. In N. Katz (Ed.), Indo-judaic studies in the twenty-first century: a view from the margin (pp. 44-56). New York, NY: Palgrave Macmillan. 


\section{Appendix A}

\section{PARTICIPANTS}

Jewish Delegation

- Chief Rabbi Yona Metzger. Israel, Chicl Rabbi of Istacl

- Mr. Oded Wiener, Israel. Direcior General, Chief Rabbinntic of lsrael

- Chief Rabbizdusidarosen. Istalel. Presidem. International dewish Commitee for Interrehgious Consultation (IJCIC): Intemational Direcior of Interreligious Affiris. Americin Jewish Conmitlec (A.JC)

- Rabbi Professor Daniel Sperber. Istael. Prolessor of Talmud and lewish Studies at Bar Ilan Universily

- Rabbi Dr. Israel Singer. USA. Chairman. International Juwish Committee for Interreligious Consultation (IJCIC): Chairman. Policy Contil of the World Jewish Congress

- Rabbi Moshe Garelik. LSA. Director of the Rabbinical Center of Furope

- Chief Rabbi Abert Guigui. Belgium. Chief Rabbi ol Belgium

- Chief Rabbi Isak Haleve. Turkey, Chict Rabbi ol Tulkey

- Chief Rubbi Benito Garcon-Serfaly. Spain. Former Cluicf Rabbi of Soan and Protessor of Iewish Sludies at the Lniversity of Madrid

Representatives of the limbassy of Israel in India

- Mr. David Danielli. Isracli Ambassador, New Delhi

- Mr. Daniel Zohar Zonshine. Consul Cieneral of lsrael. Wumbai

- Mr. Yocd Magen. Deputy Comsul General of Isracl. New Delhi

Representatives of the Jewish Community in India

- Mr. Solomon Sopher, Chaiman. Sir lacob Sasson Charity Trust \& President. Knesseth Eliyalu Synagogus. Mumbai

- Rabbi Abraham Benjamin, Mumbai

- Mr. Benjamin Rcubcn. President of the Jewish Communily in Ahmedabad

- Hr. Fina Muses. Hon Secreary \& Trustec Shar Hashamaim (Gate of lleaven) Syungogue. Mumbai

- Mr. Issac Samson, Assl. Commissimer ol Polict (Retd.). (rime Branch C.I.D branch. Mumbai

- Rabbi Joshua Kolet, Chairman. I Iazon Eli-Vision of my God. Membai

- Lt. General (Retd.) J.F.R. Jacob. Delli

- Mr. Fzekial Malekar. Hon. Sec Judah Hyan Synagugute. Neu Delhi

- Mr. Nissim Moses. Presidem, Indo-isracli Support Services. Delhi

Above: Participants of the First Hindu-Jewish Leadership Summit

Source: n/a (2007). Participants. Proceedings of the firsthindu-jewish teadership summit (pp.61-63) Nen

York, Ny: World Council of Religious leaders 


\section{Appendix B}

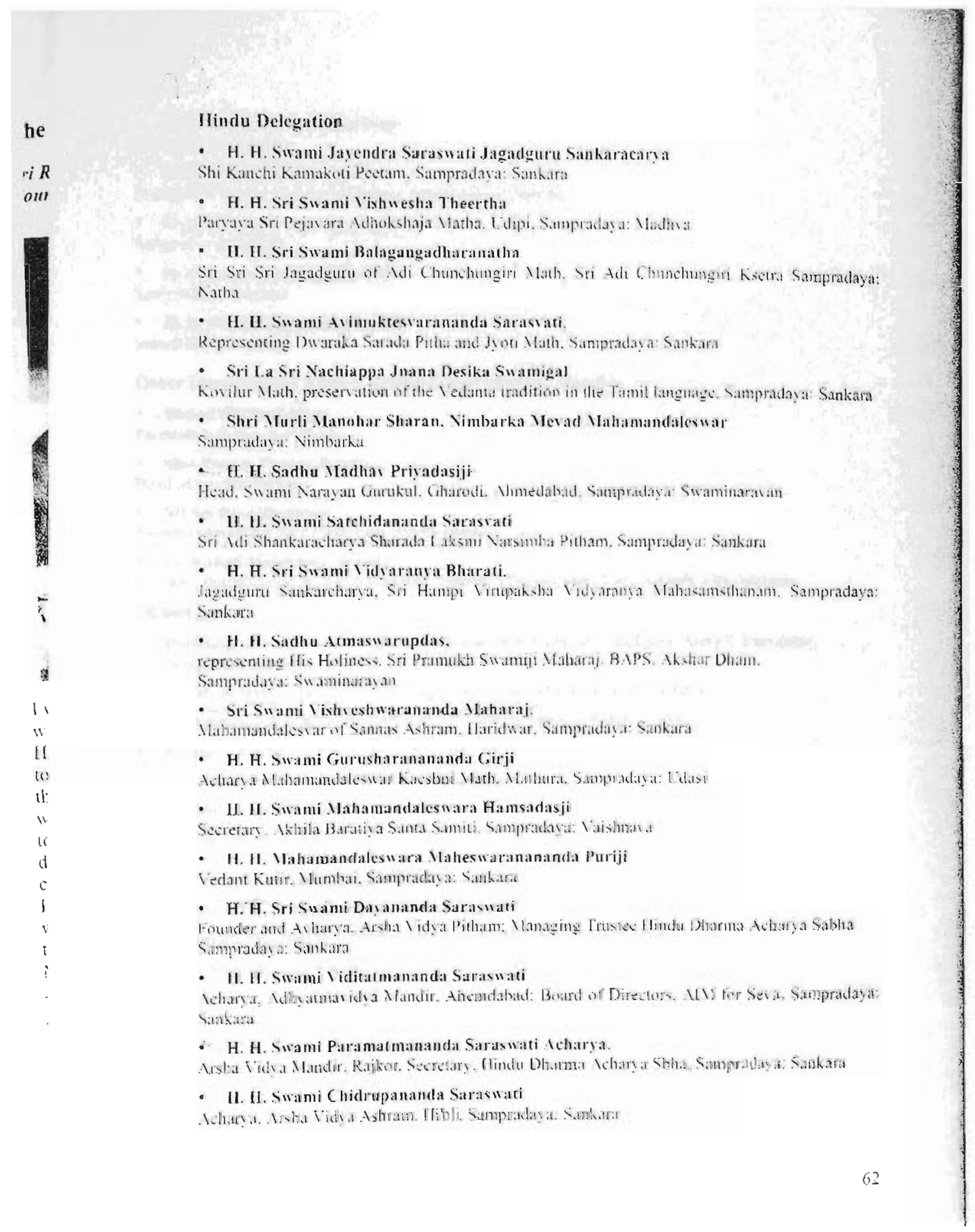

Above: Participants of the First llindu-Jewish Leadership Summit

Source: n/a (2007). Participants.Proceedings of the first hindu-jewish leadership summit (pp.61-63) New

lork, Nr: World Council of Religious Leaders 


\section{Appendix C}

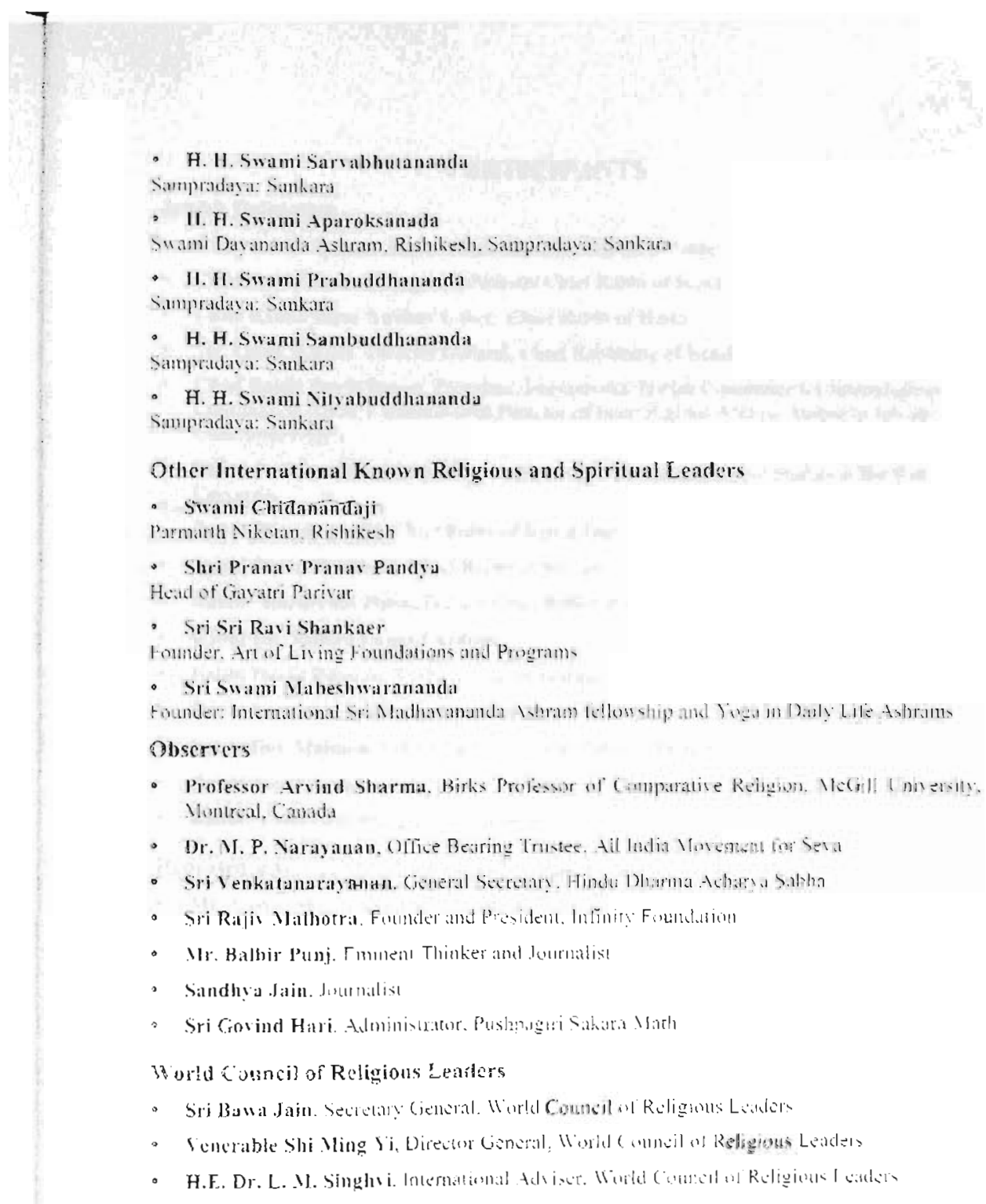




\section{Appendix D}

\section{PARTICIRAATS}

Jevish Delegatian

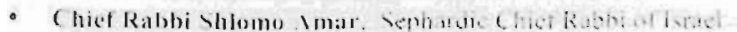

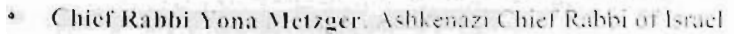

- Chicf Rabbi Shear lashus cwhen Chet Rabli of Haita

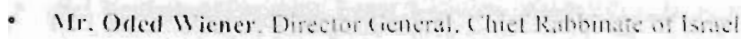

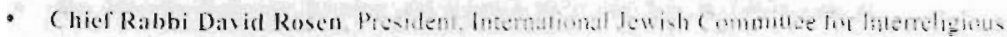

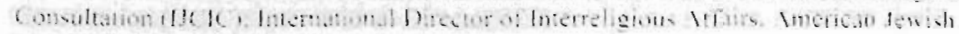
Commines ile

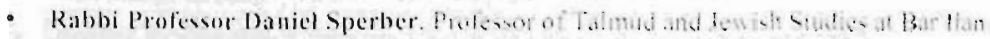
Lmasal?

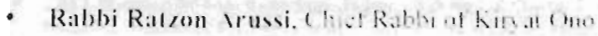

- Rabbi David Broslman Chet Rabi of sas:on

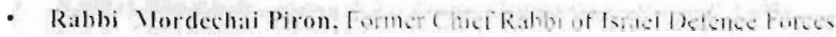

- Rabbi hr. Vathan loper (ardaze

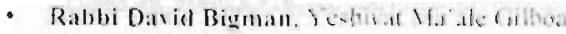

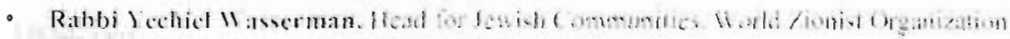

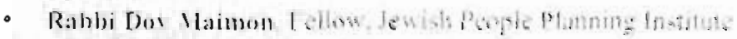

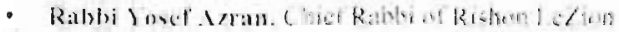

- Rabbi Jonef Glikburg. Chicf Rabor of Givatay in

Representatives of the Ministry of Boreign Athirs of ?race

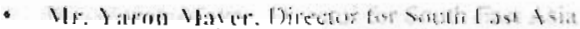

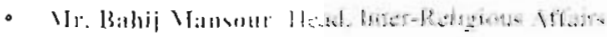

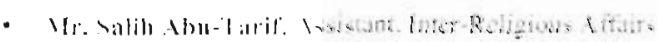

Inind Dolegation

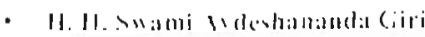

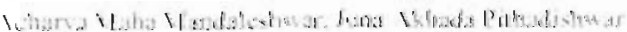

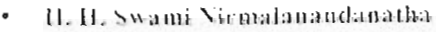

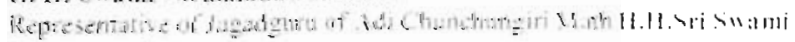

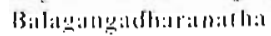

- H. II sadhu VIallas Priladiriji

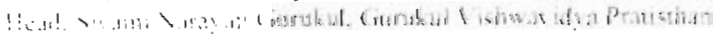

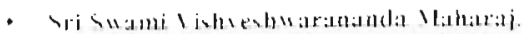

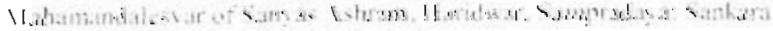

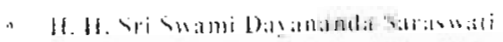

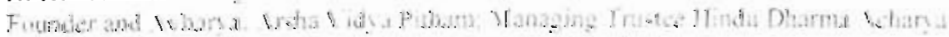

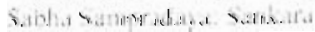




\section{Appendix E}

- H. H. Swami Sanıidananda Saraswati Maha Yandalevinar. Katilas Mlall, Vashiti

- H. H. Swami Paramatmananda Saraswati Acharya.

Sccretary. Hindu Dharma leharya Sabia, Sampradayas Sankara

- Swami Chidananda Saraswali Mani ji Parmath Vhion. Rashikesh

- Sri Venkatanarayanta. I egal Secresary. Hindu Dhama Acharya Sabha

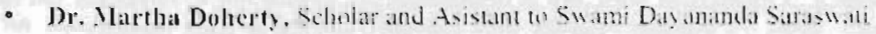

- Ms. Sheetal Shah. Hindu American Foundanum

- Mls. Inuja Prashar. Scholar and bommalast

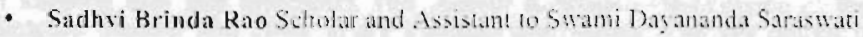

- Sri Rammurthy Govind Hari. Administrater. Puspageri Sankara Vark

- Mrs. Gawri Govind Hari. II te of Ne. Rammurh Gowin! Ilari

- Sadhvi Bhagwati. lesistane wo Simani Chidananda Saraswal Vuni ii

- Sucllu Ramsukh Das. Awislant w Sadhu Madhas Priva Das .i

- Ashotosh Wohan Gupta, Lsisant to Swanu Ardeshnanda Giri

\section{Observers}

- Deepal Mitlal. Indisi: Fnlass, Ie! Ala

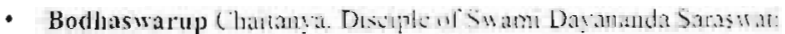

- Sharon Rosen. Wire ol Rubri Dar id Rusan

- Priva Tandon. Incicin kubla Commenllo

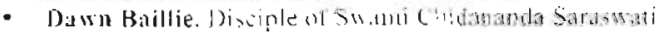

- Arril Prumislow. Assinkine m Rubla Daral Ruscr. Alc

\section{World Council of Religious l.eaders}

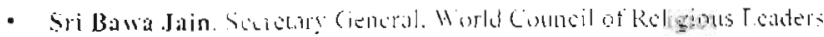

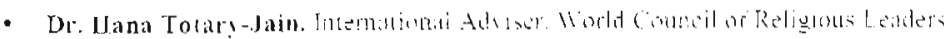




\section{Appendix F}

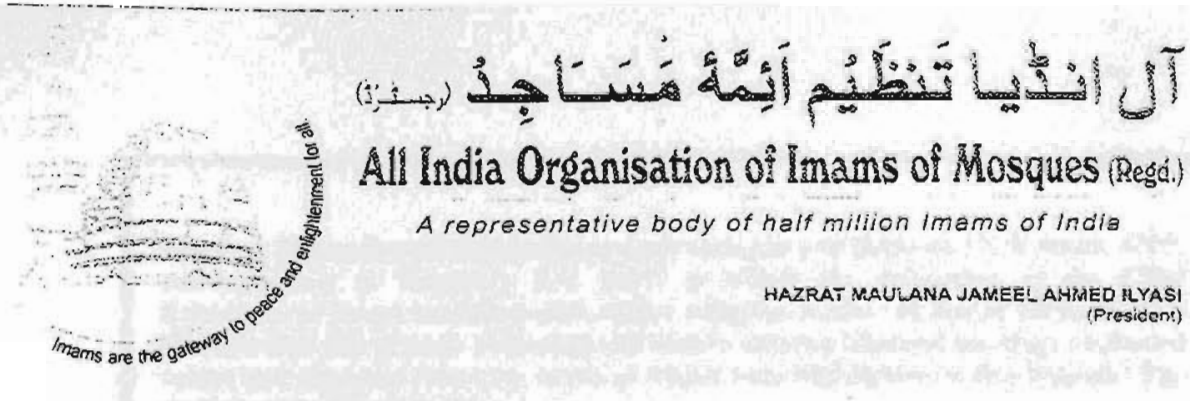

On the occasion of the visit of the detegation of the chief Rabbinate of israel to India, The Delegation held a cordial meeting with Muslim leaders of India. The Jewish Delegation welcomed he impressive statement of All lndia organization of imam of Mosques.

in keeping with this statement The Jewish \& Muslim Participants of the Meeting declared Muslim and Jews share tradition and legacy. We aie bound by history. civilization culture, common values. From Adam to Moses there is everything that unites us and even thereafter Islam through Quranic injunctions calls upon Muslims to treat Jews as Ah-e-Kitab and the believes in Judaism as God fearing people.

Similarly Judaism views Muslims as the believer in $n$ god require that they be treated with full dignity. While relations with Jews and Musiims have been influenced regularly in recent years by political factors. We have a long history of good and healthy relations between us. We declare that it is high ime for the religious ieaders of both sides to engage in dialogue and use their collective influence to stop the bloodshed of innocent civilians. We condemn killing, reject extremism and the misuse of religion of acts of violence. Suicide is a forbidder act in isian and Judaism and therefore suicidal attacks cannot find sanction neither in islam nor in Judaism.

We pledge ourselves to work together to promote the sanctity of life and to acivance justice and peace.

We appreciate the role of ieadership of the World Council of Reigious leaders in this direction.

Souiana Jameel Ahmed llyasi

Chief Rabbi Yona Metzger, Israei

Presidént

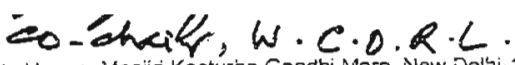

a Office : Big City House, Masjid Kasturba Gandhi Marg. New Delni-1100 0i (!ndia)

Tel, : 23385777 Telefax : 23385963 Nobi:e : 98 i1641786. 987394 io6

E-mail : into@imamindia.tripod.com i intaminsie@mailcty.com

Above: Signed declaration with the All India Organisation of Imams and Mosques

Source: n/a (2007). Proceedings of the first hindu-jewish leadership summit (pp.67) Vew York, Ni:

World Council of Religious leaders 


\section{Appendix G}

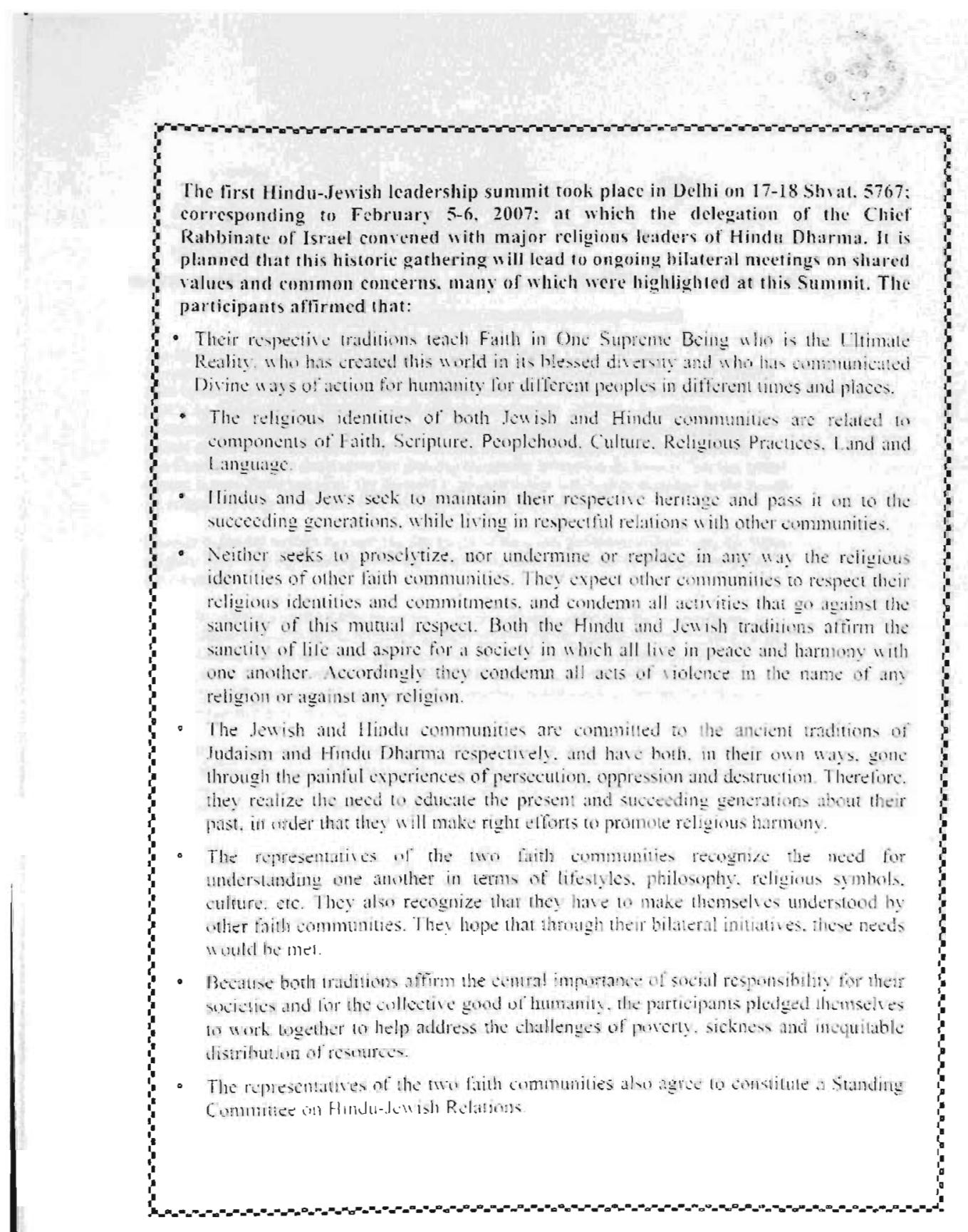

Above: Declaration of the First Hindu-Jewish I,eadership Summit

Source: n/a $(2007)$. The declaration of mutual understanding and cooperation. Proceedings of the first

hindu-jewish leadership summil (pp. 45-46) New York, NY: World Council of Religious Leaders 


\section{Appendix H}

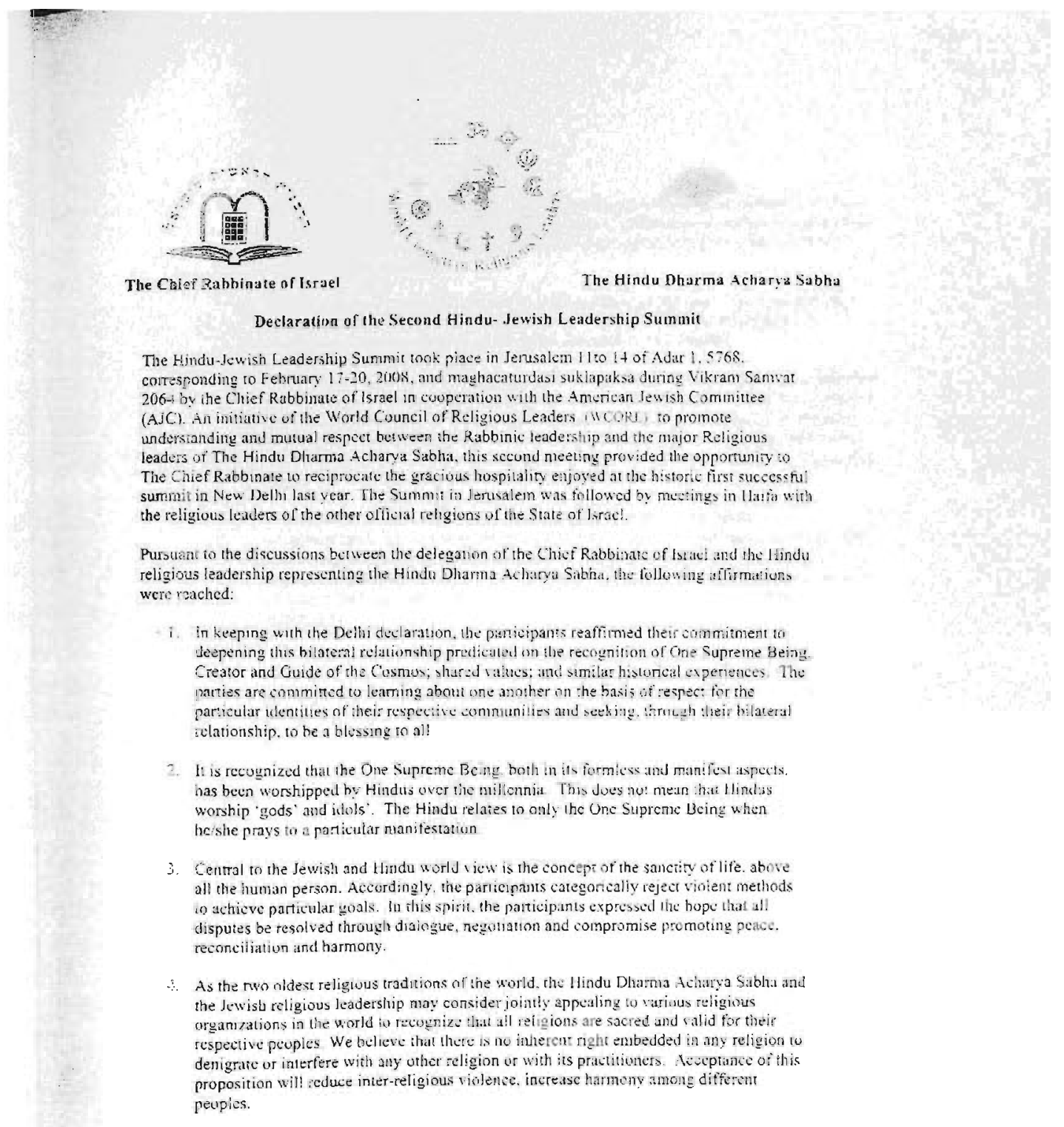

Above: Declaration of the Second IIndu-Jewish Leadership Summit

Source: n/a (2008). The declaration of the second Hindu-Jenish l.eadership Summit. Proceedings of the

second hildu-jewish leadership summit (pp.8-9) Nen York, Yl: World (ouncilof Religious leaders 


\section{Appendix I}

5. The paricipants expressed the hope that the profound wellsprings of spiritualify in their respective traditions will serve their communities to constmetively address the challenges of modernity, so that contemporary innovation may serve the highest ideals of their respective religious traditions.

6. In the interests of promoting ine correct understanding of Judaism, Hinduism and their histories, it was agreed that text books and referencc material may be prepared in consultation with the scholars group under the aegis of this Summit.

7. Svastika is an ancient and greatly auspicious symbol of the Hindu tradition. It is inscribed on Hindu temples, ritual altars. entrances, and even account books. A distorted version of this sacred symbol was misappropriated by the Third Reich in Gernany, and abused as an emblem under which hcinous crimes werc perpetrated against humanity. particularly the Jewish people. The participants recognize that this symbol is. and has been sacred to Hindus for millennia, long beforc its misappropriation.

8. Since there is no conclusive cvidence to suppont the theory of an Aryan invasionimigration into India, and on the contrary, there is compelling evidence to refute it; and since the theory seriously danages the integrity of the Hindu tradition and tis comection to India: we call for a serious reconsideration of this theory, and a revision of all educational material on this issue that includes the most recent and reliable scholarship.

9. The bilateral group of scholars may cugage in further elaboration of the foregoing affirmations, exchange material to enhance mutual understanding. clarify the positions of the Hindu and Jewish traditions rcgarding contemporary challenges in science and society, and identify programs of action for the furure.
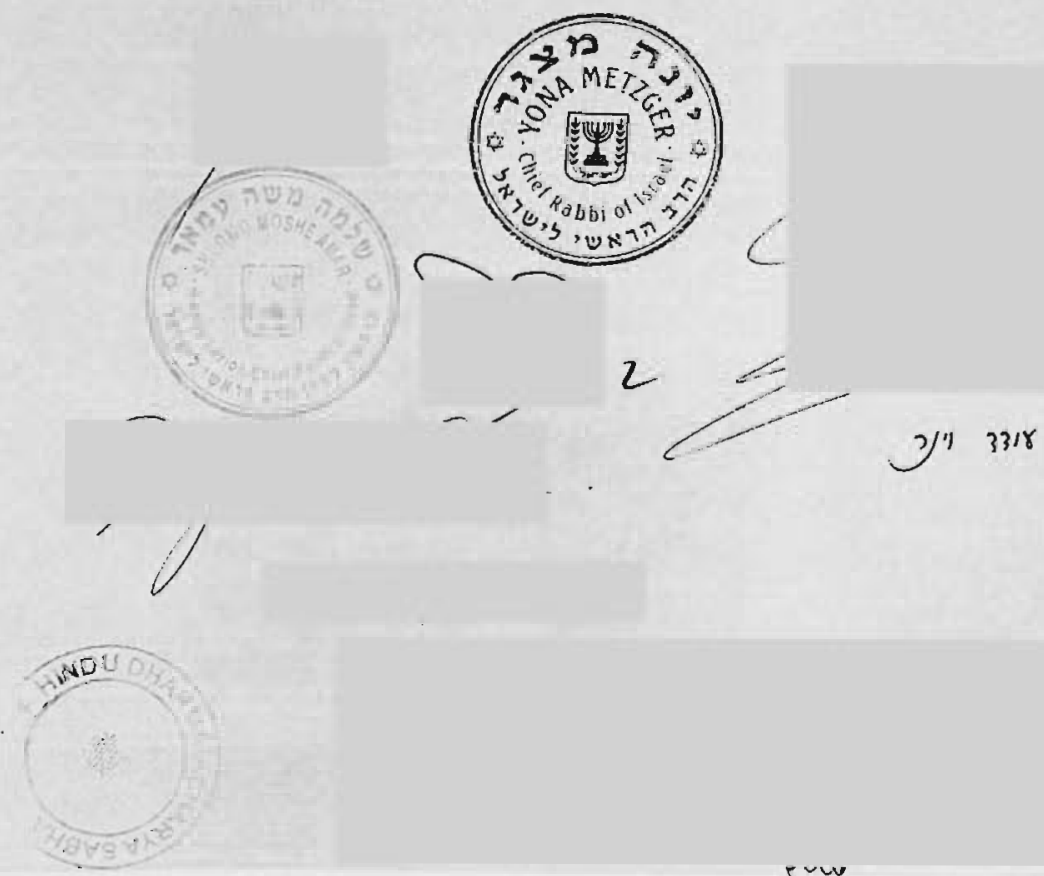

Above: Declaration of the Second Hindu-Jewish L.eadership Summit

Source: n/a $(2008)$. The declaration of the second Hindu-Jenish Leadership summit. Proceedings of the

second hindu-jewish leadership summit (pp.8-9) New York, Ny: World Council of Religious Leaders 